ANL-6916

Chemistry

(TID-4500, 34th Ed.)

AEC Research and

Development Report

\author{
ARGONNE NATIONAL LABORATORY \\ 9700 South Cass Avenue \\ Argonne, Illinois 60440
}

\title{
INDEX AND DISPERSION OF SOME \\ CERENKOV COUNTER GASES
}

by

E. R. Hayes, R. A. Schluter
and A. Tamosaitis

High Energy Physics Division

August 1964
Operated by The University of Chicago under
Contract W-31-109-eng-38
with the

U. S. Atomic Energy Commission 


\section{DISCLAIMER}

This report was prepared as an account of work sponsored by an agency of the United States Government. Neither the United States Government nor any agency Thereof, nor any of their employees, makes any warranty, express or implied, or assumes any legal liability or responsibility for the accuracy, completeness, or usefulness of any information, apparatus, product, or process disclosed, or represents that its use would not infringe privately owned rights. Reference herein to any specific commercial product, process, or service by trade name, trademark, manufacturer, or otherwise does not necessarily constitute or imply its endorsement, recommendation, or favoring by the United States Government or any agency thereof. The views and opinions of authors expressed herein do not necessarily state or reflect those of the United States Government or any agency thereof. 


\section{DISCLAIMER}

Portions of this document may be illegible in electronic image products. Images are produced from the best available original document. 
$$
\text { . }
$$ 


\title{
INDEX AND DISPERSION OF SOME CERENKOV COUNTER GASES
}

by

\author{
E. R. Hayes, R. A. Schluter, \\ and $A$. Tamosaitis
}

\begin{abstract}
The index of refraction, $n$, and dispersion of several Cerenkov counter gases has been precisely measured by the interferometric method. The precision is typically four parts in $(\mathrm{n}-1) \times 10^{5}$.

The gases investigated include Freon $12\left(\mathrm{CCl}_{2} \mathrm{~F}_{2}\right)$; Freon $13\left(\mathrm{CC}_{3} \mathrm{~F}_{3}\right)$; Freon $13 \mathrm{~B} 1\left(\mathrm{CBrF}_{3}\right)$; Freon $22\left(\mathrm{CHClF}_{2}\right)$; Freon $116\left(\mathrm{CF}_{3}-\mathrm{CF}_{3}\right)$; Freon 218 (Perfluoropropane); Per fluorobutane $\left(\mathrm{C}_{4} \mathrm{H}_{10}\right)$, as well as nitrogen, carbon dioxide, and dry air. Measurements of $n$ were made at $5460 \AA, 4360 \AA$, $4050 \AA, 3650 \AA$ and $3125 \AA$. For Freon 13 and carbon dioxide the measurements were carried to pressures near the critical point.
\end{abstract}

The indices of refraction and dispersions of several gases (some "Freon" compounds, nitrogen, carbon dioxide and dry air) suitable for use in Cerenkov counters have been determined. Measurements of a limited range were made earlier here ${ }^{1}$ and elsewhere. ${ }^{2}$

The present results for the Freons are over the range from $n=1.000$ to $\mathrm{n}=1.058$, which corresponds to a lower limit of $\beta=0.9487$ at a Cerenkov angle of $5^{\circ}$.

The interferometer consisted of two parallel quartz plates separated by a nominal $30 \mathrm{~mm}$ and illuminated by a $\mathrm{Hg}^{198}$ bulb. Interference filters were used to isolate the desired wavelengths.

Counting was accomplished by a photomultiplier that detected variations in the fringe pattern and a scaler indicating the counts.

The procedure for counting was to evacuate the vessel to a pressure of $5 \mu$ and refill with the desired gas, allowing sufficient time for temperature stabilization. Gas was then slowly bled from the system while the

$1_{E}$. R. Hayes et al. Index of Refraction and Dispersion of Freon 13 and Other $G$ ases as Functions of Pressure, High Energy Physics Division, Argonne National Laboratory (Sept 1963).

2 W. Galbraith, G. Manning and A. G. Parham, Refractive Index Measurements in a $G$ as Cerenkov Counter, AERE -R 3867. 
pressure was read from a "Heise" 0-1000 psia gage with a precision of $\pm 1 / 2^{\circ}$ psi at any pressure. Temperature was measured with a potentiometer, by means of a copper-constantan junction located inside the test vessel.

No comparison of the molecular refractivities as calculated from the Lorentz-Lorenz law with the summed atomic refractivities was made due to lack of precise pressure-density information near the critical points. Such a comparison was made previously ${ }^{l}$ and found in good agreement at lower pressures.

calibration was verified

The interferometer by comparing the measured index of refraction of nitrogen with the values reported by Bennett. 3 The results agree within the precision range of the Heise gage, as shown by Table I.

Table I

INDEX OF REFRACTION OF NITROGEN AT $5460 \AA$

\begin{tabular}{|c|c|c|}
\hline \multirow{2}{*}{$\begin{array}{c}\text { Pressure, } \\
\text { psia }\end{array}$} & \multicolumn{2}{|c|}{$(n-1) \times 10^{5}$} \\
\hline & Measured & C. F. Bennett \\
\hline 20 & 38.3 & 37.3 \\
\hline 40 & 77.5 & 76.6 \\
\hline 100 & 187 & 188 \\
\hline
\end{tabular}

Experimental errors resulting from the counting of whole fringes, as well as from temperature and pressure measurements, are estimated to be four parts in $(n-1) \times 10^{5}$.

The minimum purity of the gases is quoted from the Matheson Catalog as: Freon $13-99.0 \%$; Freon 13B1 - 99.0\%; Freon $12-99.0 \%$; Freon 22 $99.9 \% ; \mathrm{CO}_{2}-99.5 \% ; \mathrm{N}_{2}-99.7 \%$.

A list of the measurements is given in Table II, and individual curves follow. Graphs of the indices of refraction in $11 \times 17$-in. size are available upon request.

${ }^{3}$ C. F. Bennett, Dispersion and Refractive Index of Nitrogen Measured as Functions of Pressure by Displacement Interferometry, Phys. Rev., $37,263(1931)$. 
Table II

LIST OF REFRACTIVE INDEX MEASUREMENTS

Range of Measurements

Critical Pressure and Temperature

I. Air

Air
$\lambda-5460 \AA$
$3125 \AA$

pressure $=0-1000 \mathrm{psia}$

temp $=26^{\circ} \mathrm{C}$

II. Nitrogen

$\lambda-5460 \AA$

$3125 \AA$

pressure $=0-1000$ psia

temp $=24^{\circ} \mathrm{C}$

III. Carbon Dioxide $\left(\mathrm{CO}_{2}\right)$

$$
\begin{array}{r}
\lambda-5460 \AA \\
4360 \AA \\
4050 \AA \\
3125 \AA
\end{array}
$$

pressure $=0-1000$ psia temp $=30^{\circ} \mathrm{C}$

1072 psia, $31^{\circ} \mathrm{C}$

pressure $=0-88 \mathrm{psia}$

temp $=26^{\circ} \mathrm{C}$

596.9 psia, $112^{\circ} \mathrm{C}$

$4360 \AA$

$4050 \AA$

$3650 \AA$

$3125 \AA$

V. Freon $13\left(\mathrm{CClF}_{3}\right)$

$$
\begin{array}{r}
-5460 \AA \\
4360 \AA \\
4050 \AA \\
3650 \AA \\
3125 \AA
\end{array}
$$

pressure $=0-510$ psia

temp $=27.1^{\circ} \mathrm{C}$

561 psia, $28.9^{\circ} \mathrm{C}$

VI. Freon 13B $\left(\mathrm{CBrF}_{3}\right) \mathrm{M}$ ) Srir:

$$
\begin{array}{r}
\lambda-5460 \AA \\
4360 \AA \\
3650 \AA \\
3125 \AA
\end{array}
$$

pressure $=0-160$ psia

temp $=26^{\circ} \mathrm{C}$

575 psia, $67^{\circ} \mathrm{C}$

VII. Freon $22\left(\mathrm{CHClF}_{2}\right)$

$\lambda-5460 \AA$ $4360 \AA$

pressure $=0-140 \mathrm{psia}$

temp $=26^{\circ} \mathrm{C}$

VIII. Freon $116\left(\mathrm{CF}_{3}-\mathrm{CF}_{3}\right)$

$$
\begin{array}{r}
-5460 \AA \\
4360 \AA \\
3650 \AA \\
3125 \AA
\end{array}
$$

pressure $=0-200 \mathrm{psia}$

temp $=26^{\circ} \mathrm{C}$

$480 \mathrm{psia}, 24.3^{\circ} \mathrm{C}$

IX. Freon 218 (Perfluoropropane)

$$
\begin{array}{r}
\lambda-5460 \AA \\
4360 \AA \\
3650 \AA \\
3125 \AA
\end{array}
$$

pressure $=0-90$ psia

temp $=26^{\circ} \mathrm{C}$

390 psia, $71.9^{\circ} \mathrm{C}$

X. Perfluorobutane $\left(\mathrm{C}_{4} \mathrm{H}_{10}\right)$

$$
\begin{array}{r}
-5460 \AA \\
3650 \AA \\
3125 \AA
\end{array}
$$

pressure $=0-30 \mathrm{psia}$

temp $=26^{\circ} \mathrm{C}$

716 psia, $96^{\circ} \mathrm{C}$

\author{
${ }^{\circ} \mathrm{C}$
}



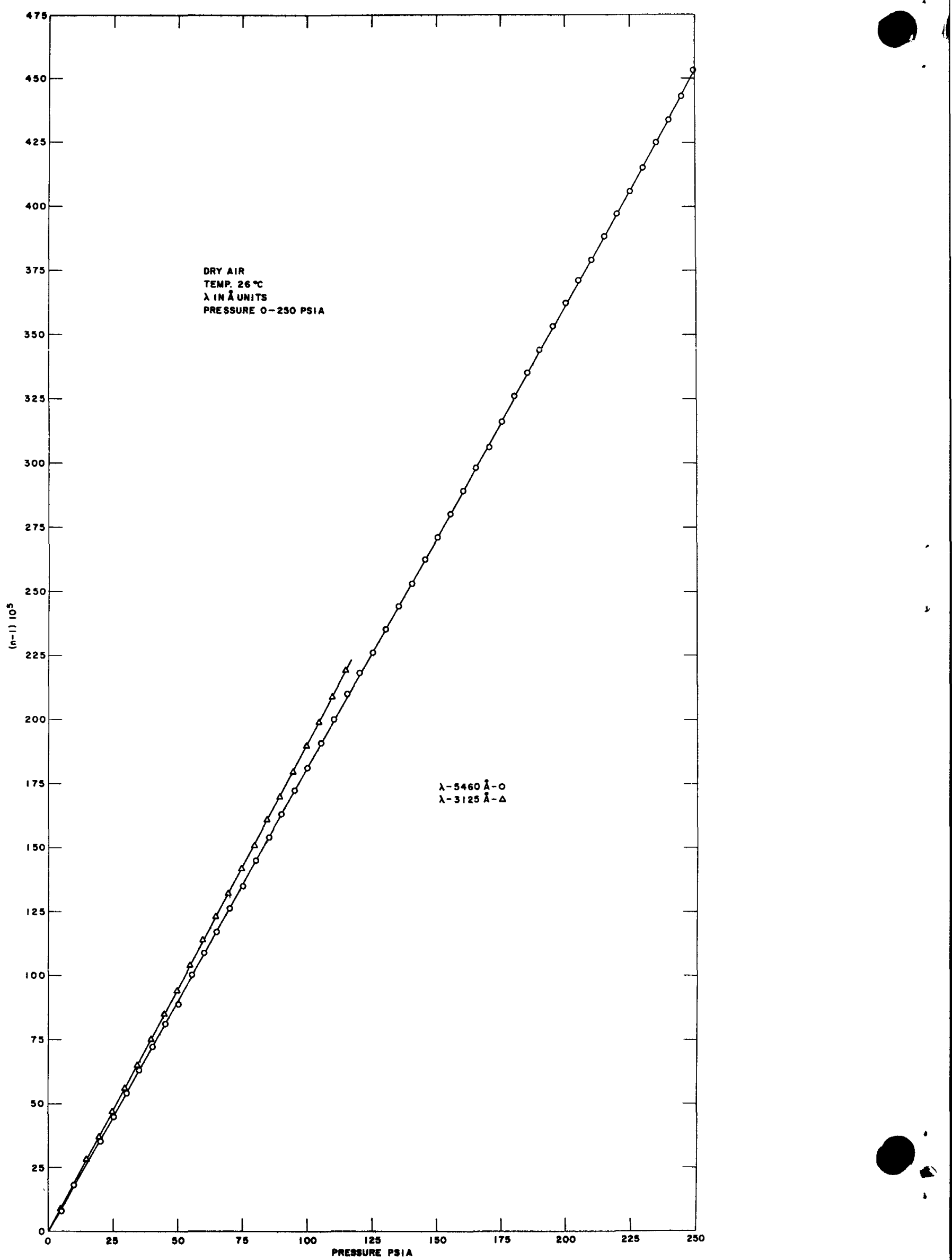
7

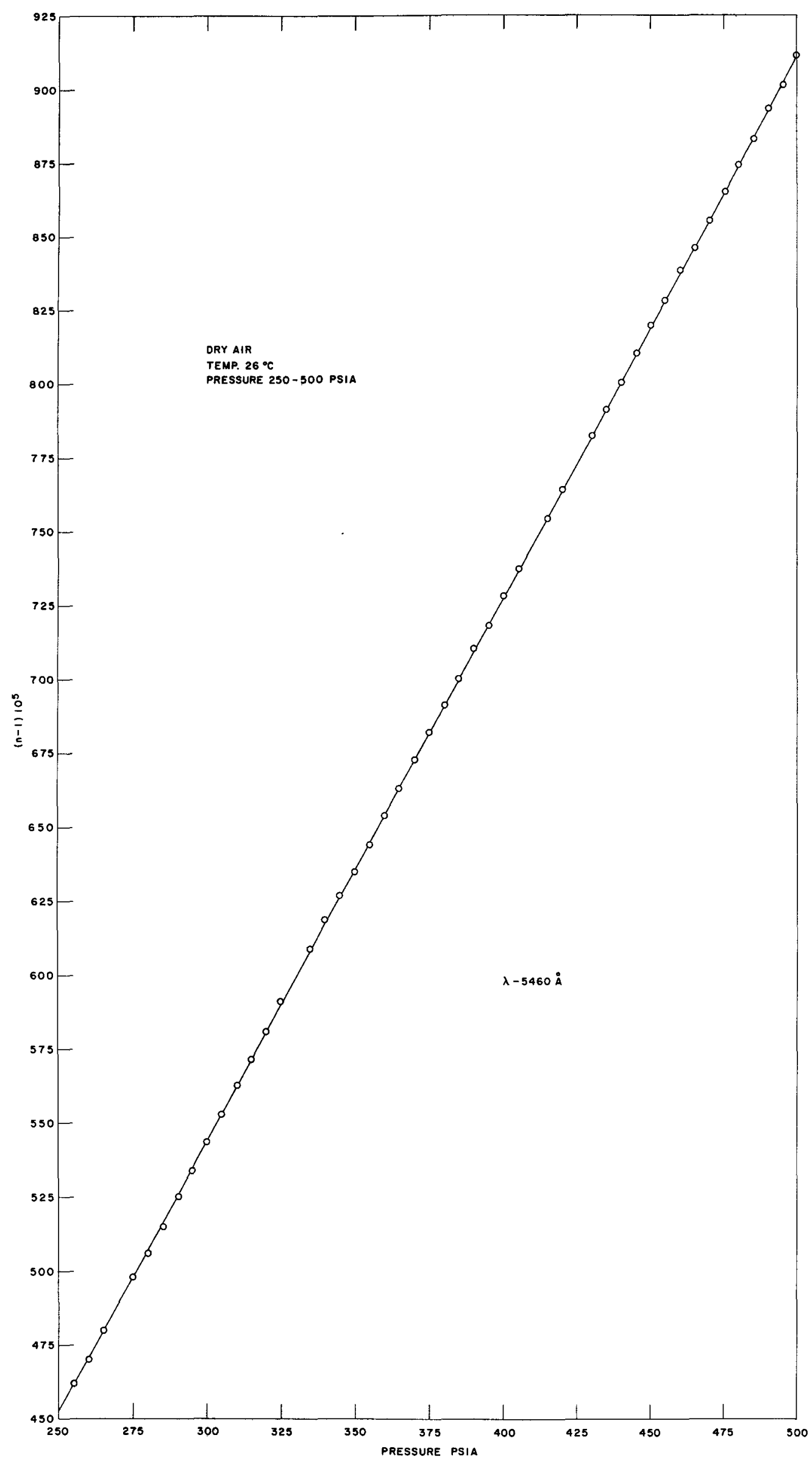




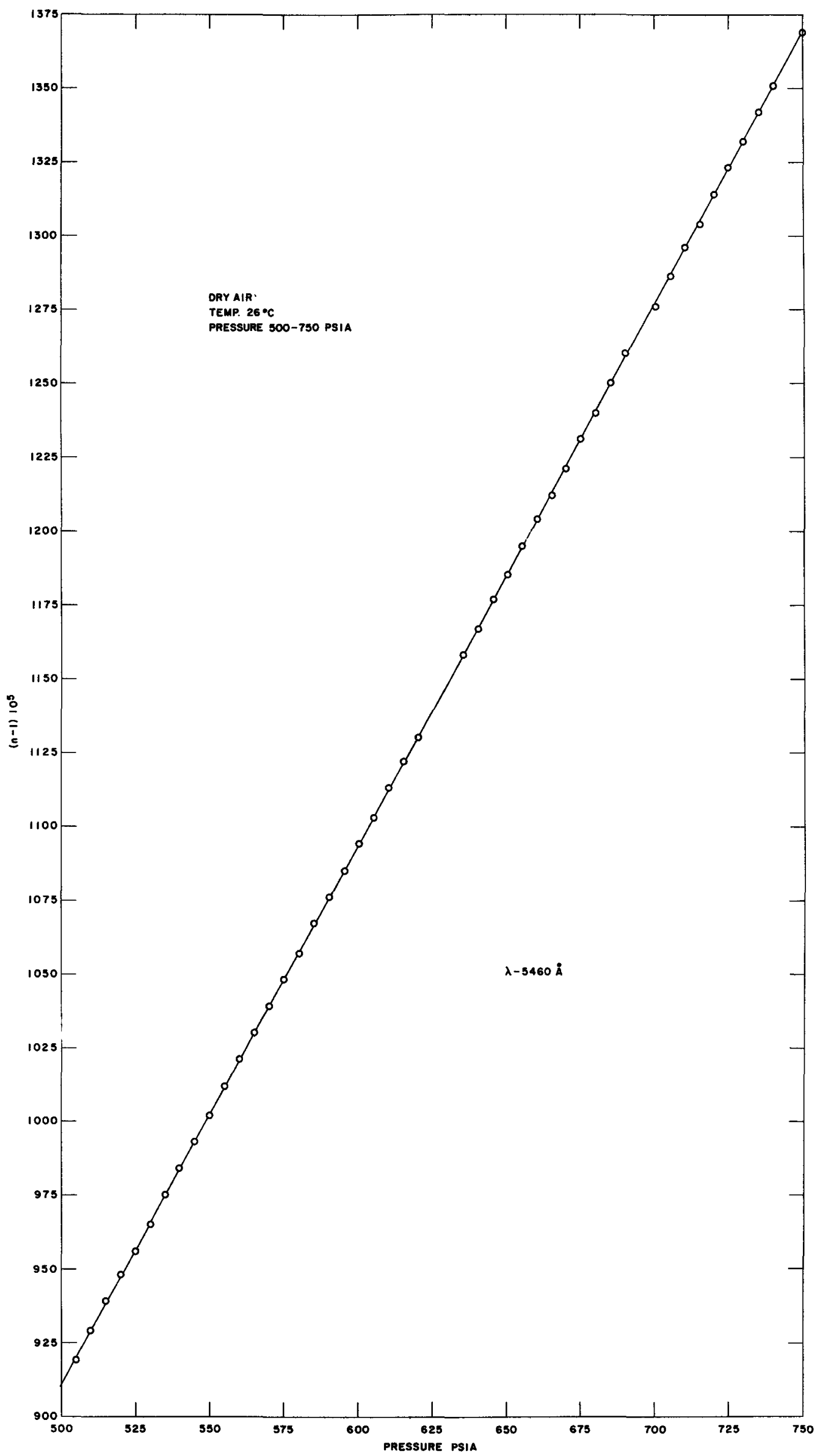



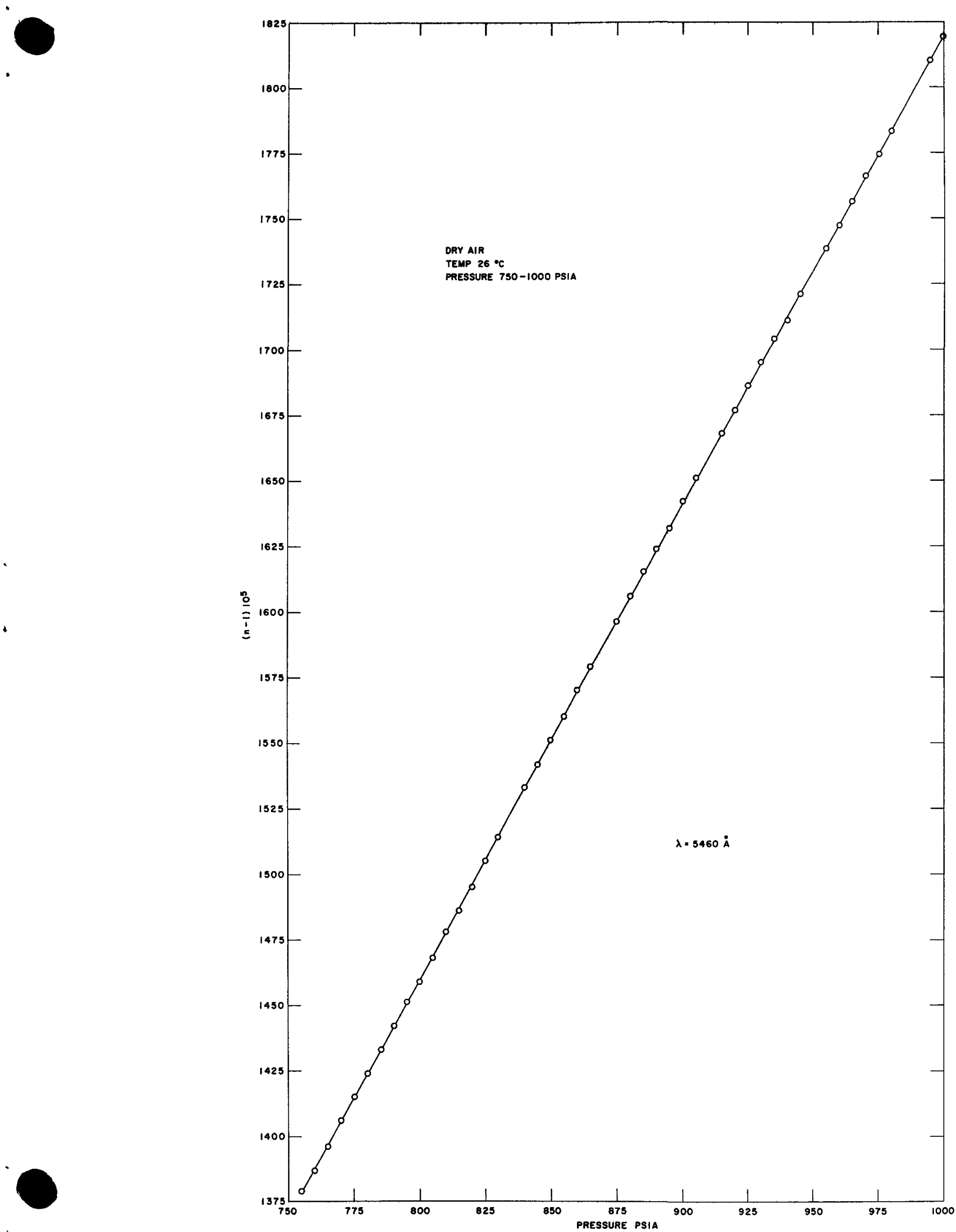


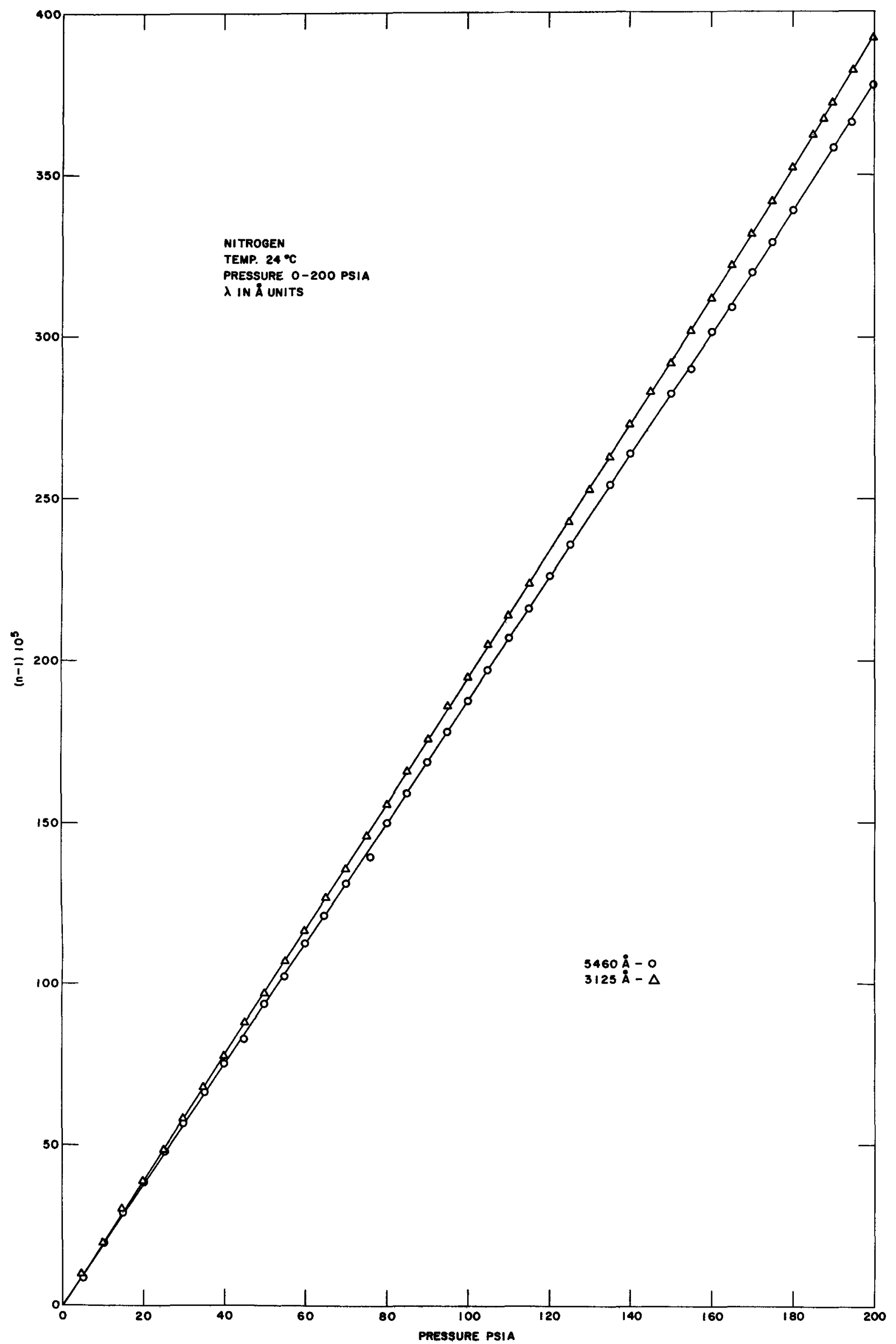




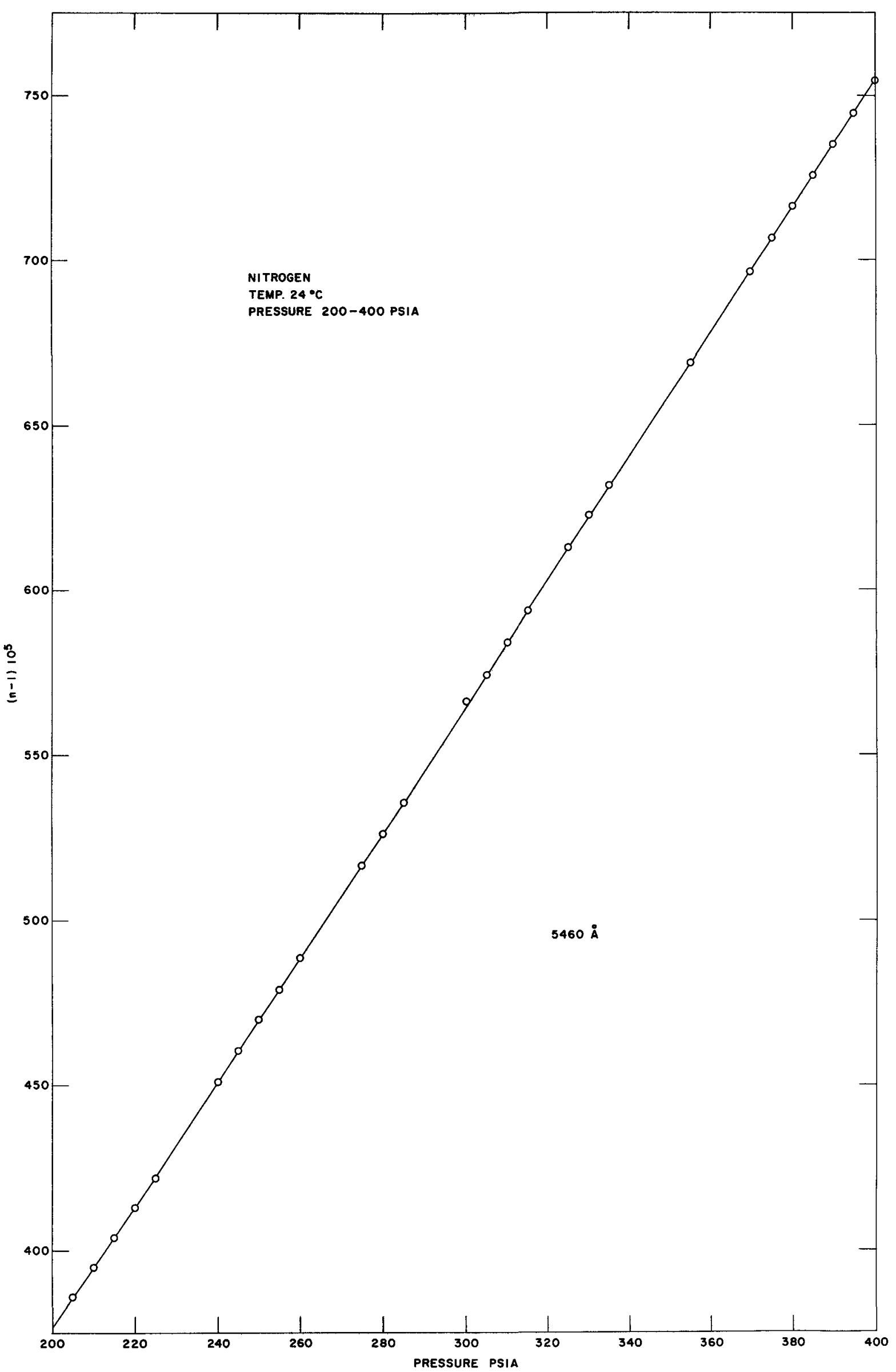




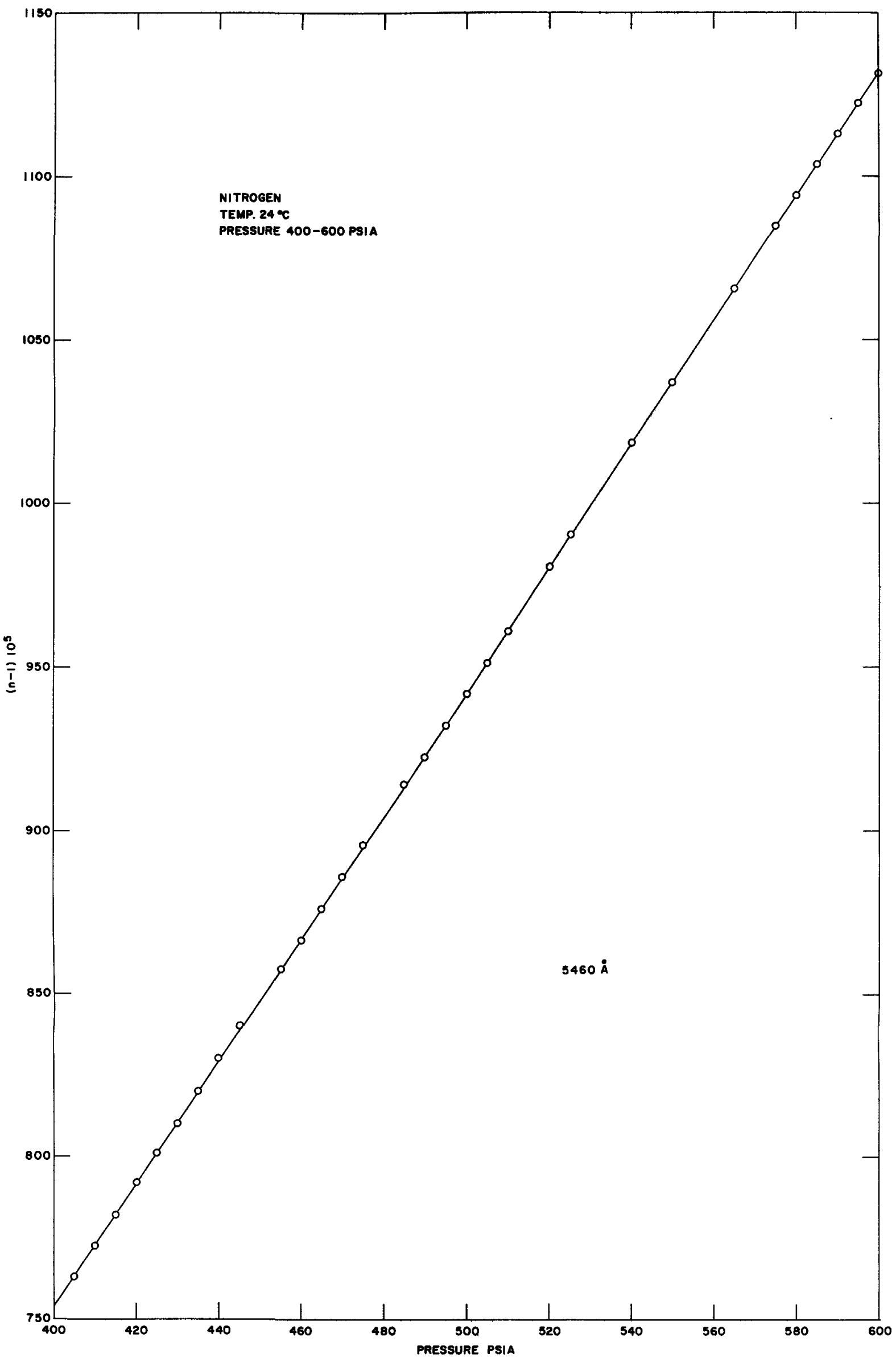




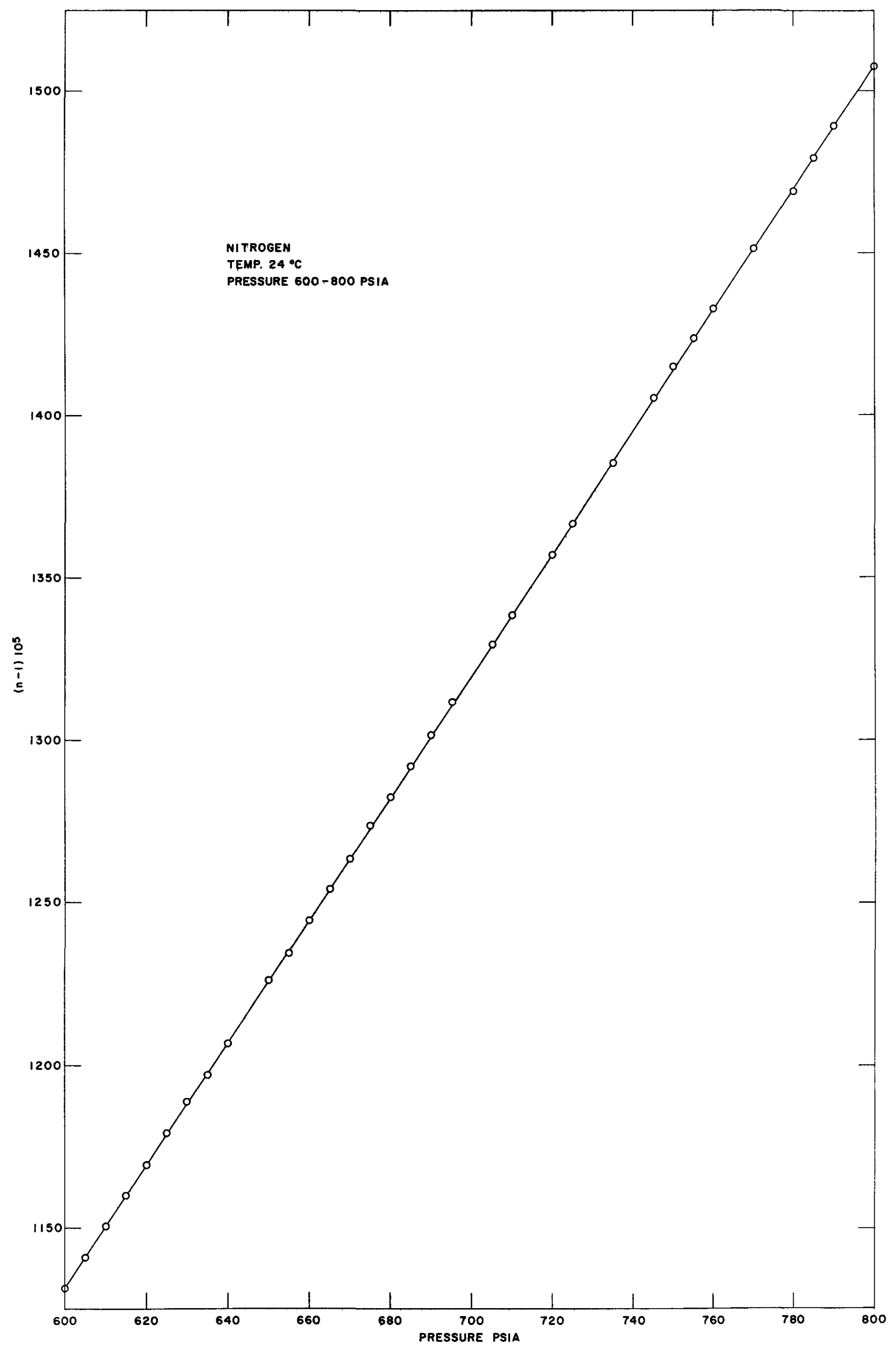




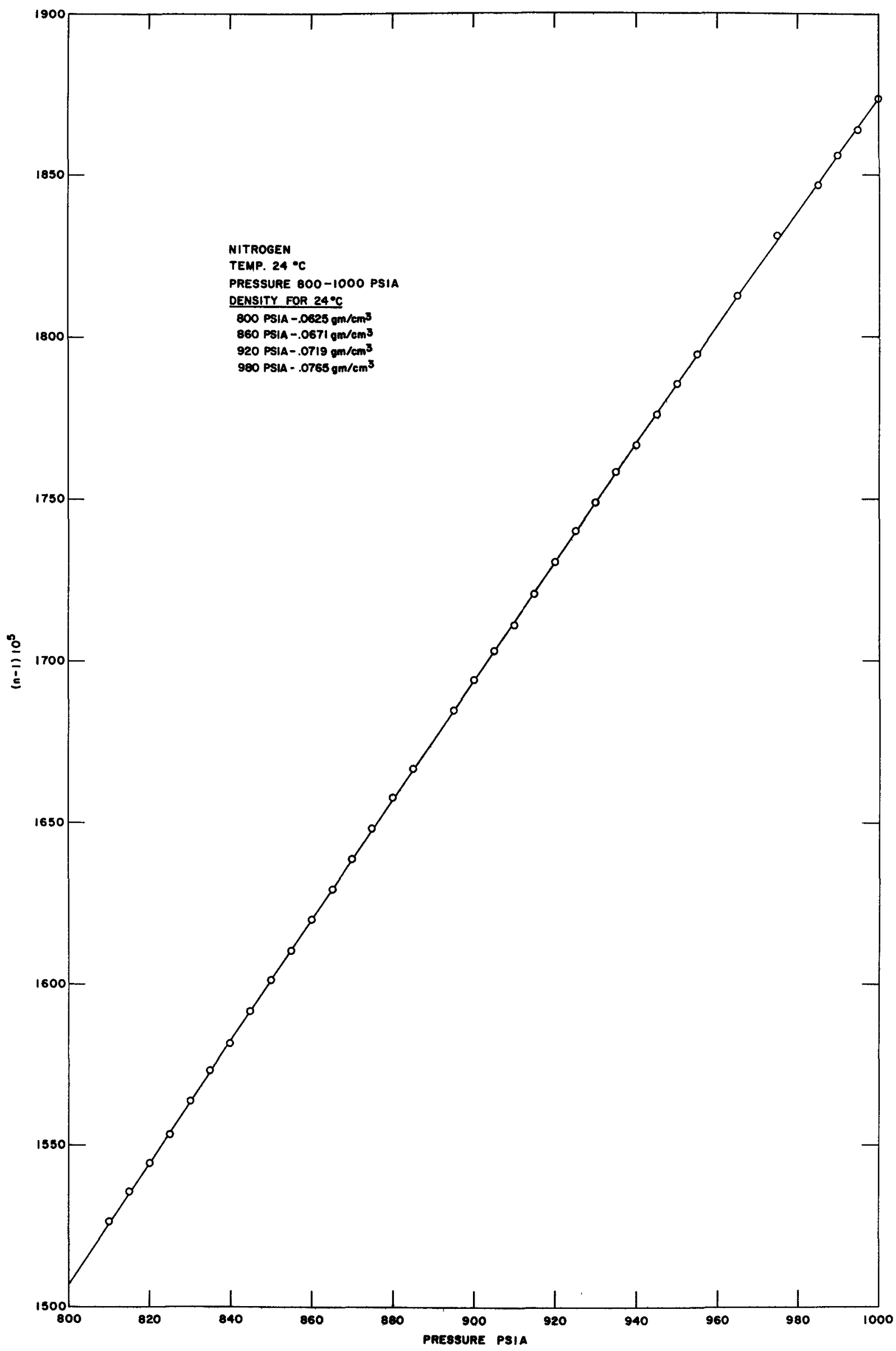


15

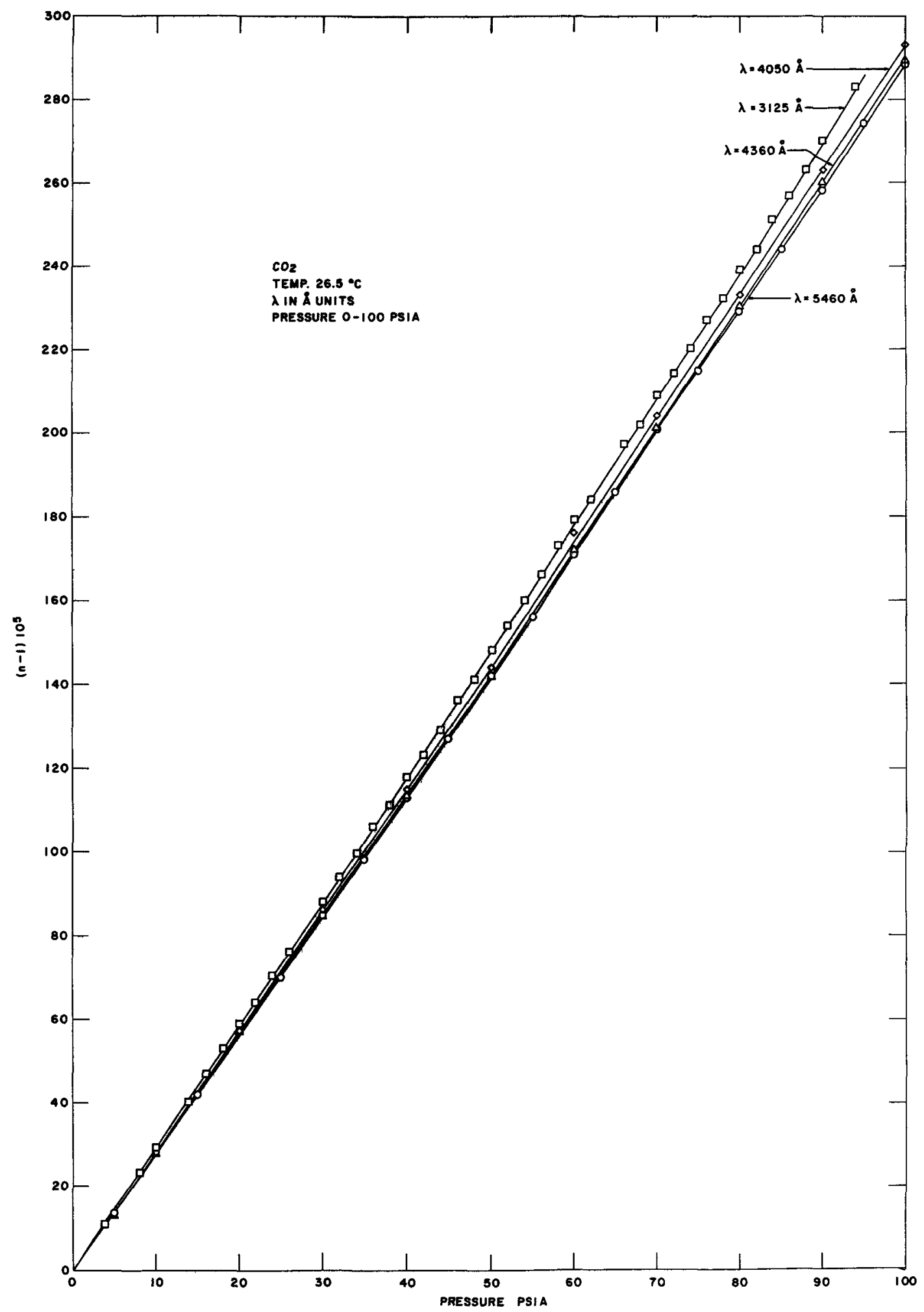




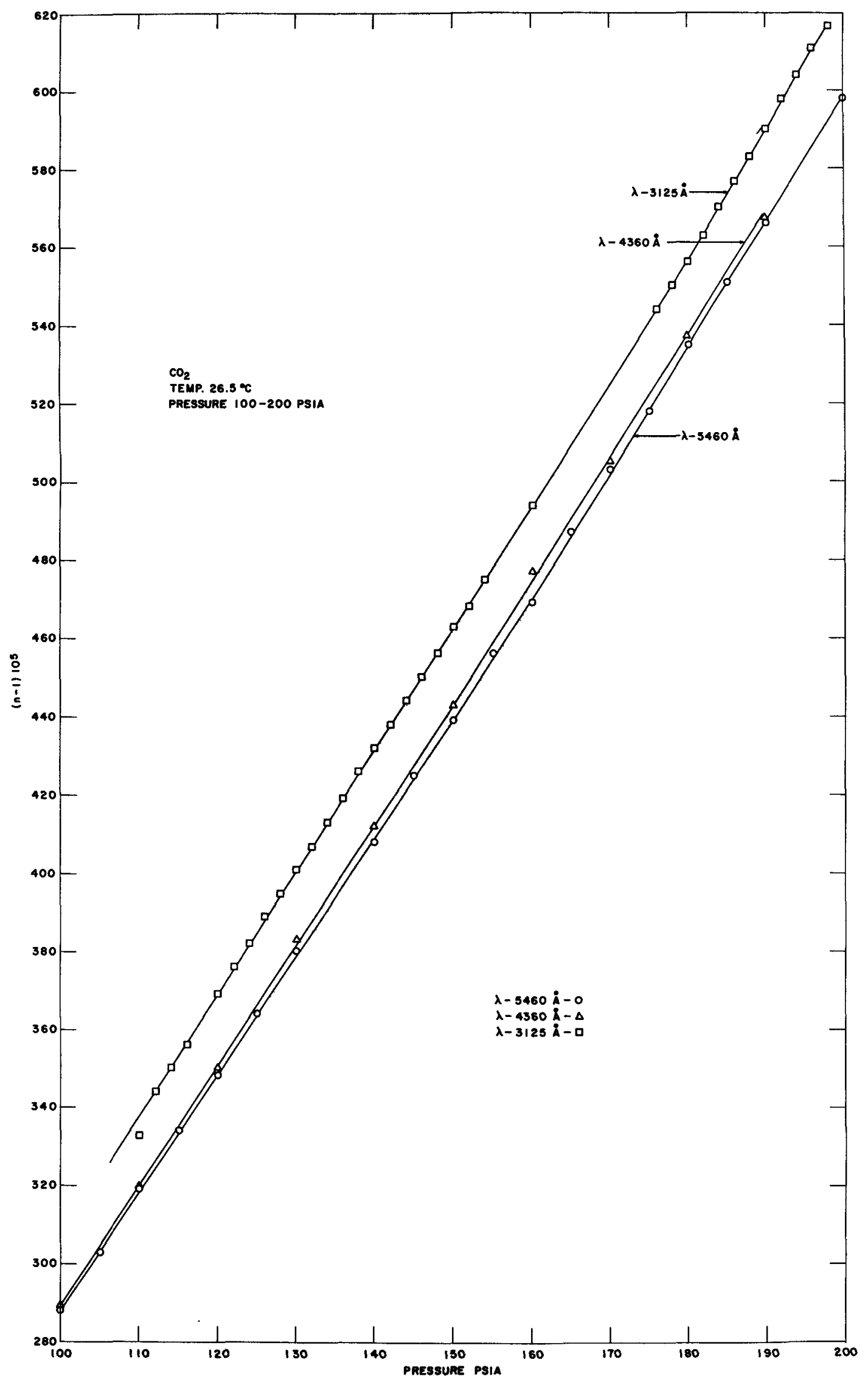




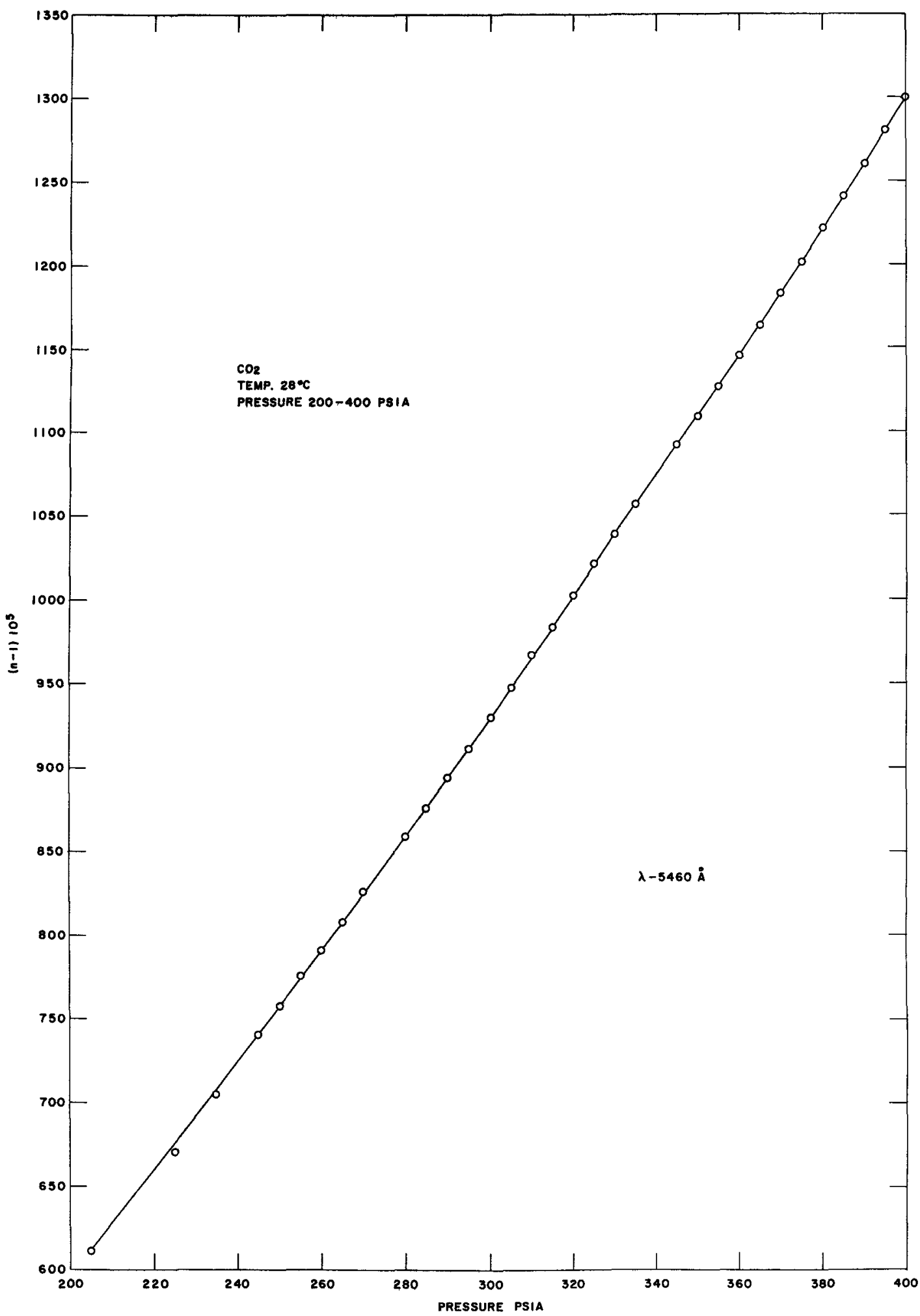




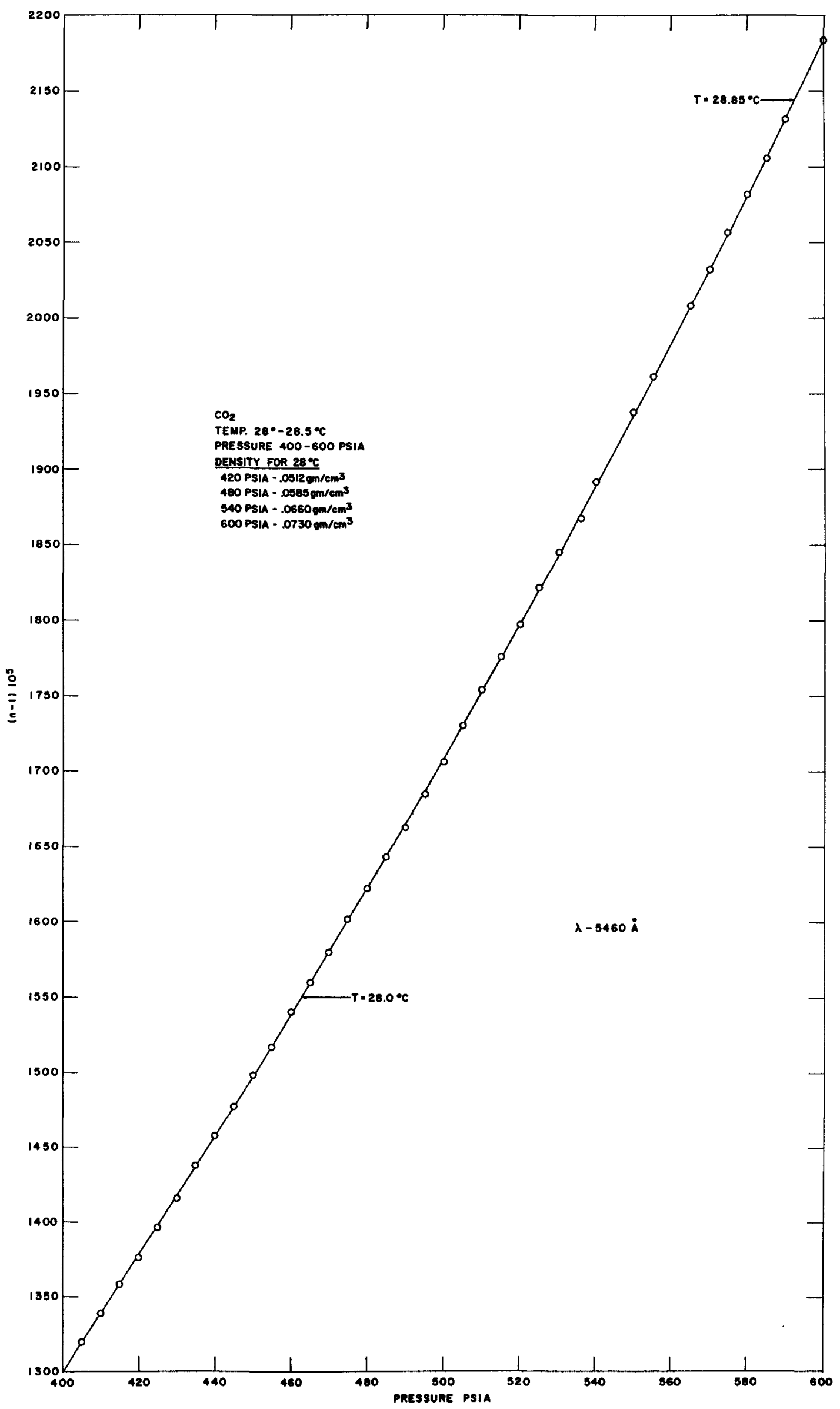




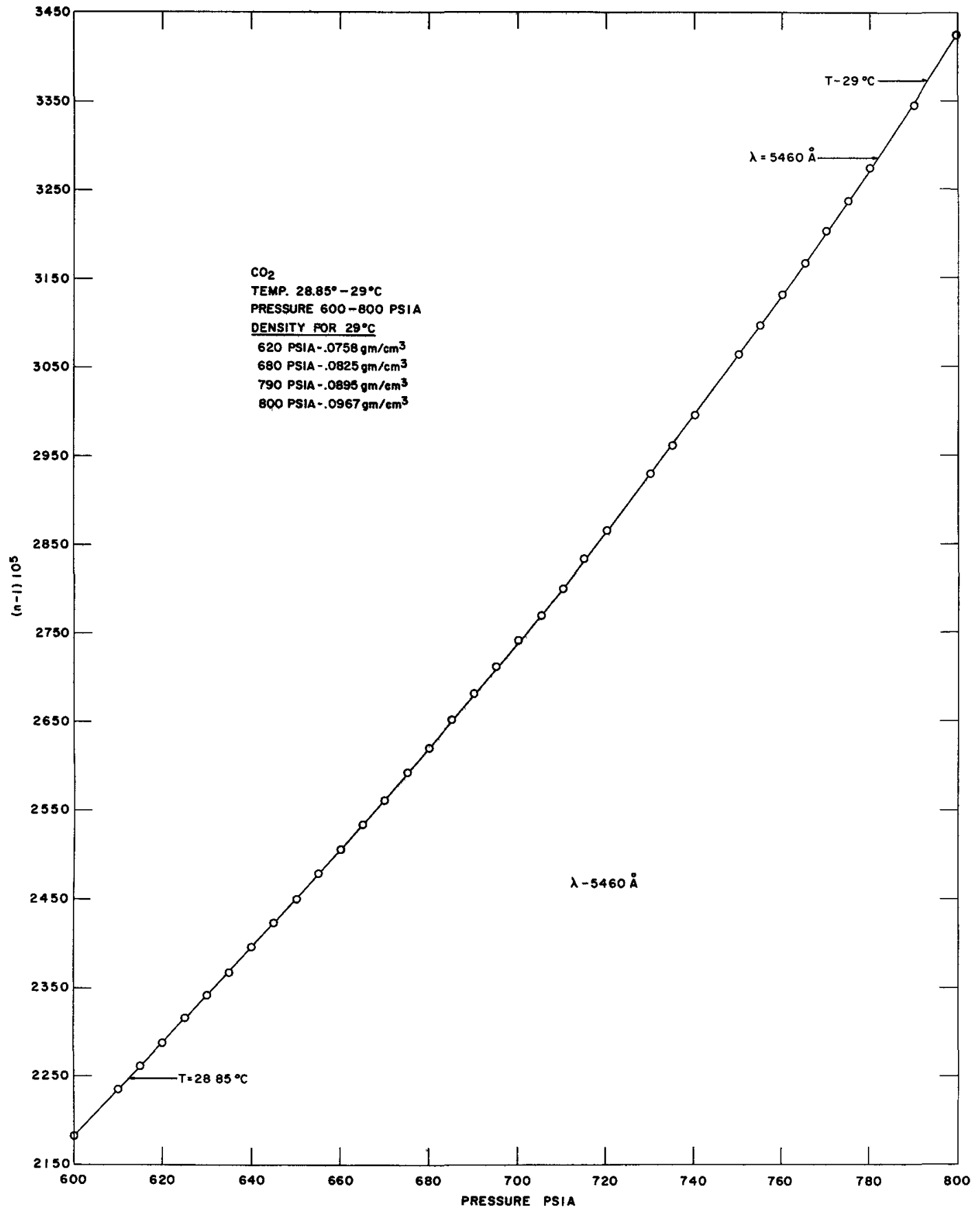




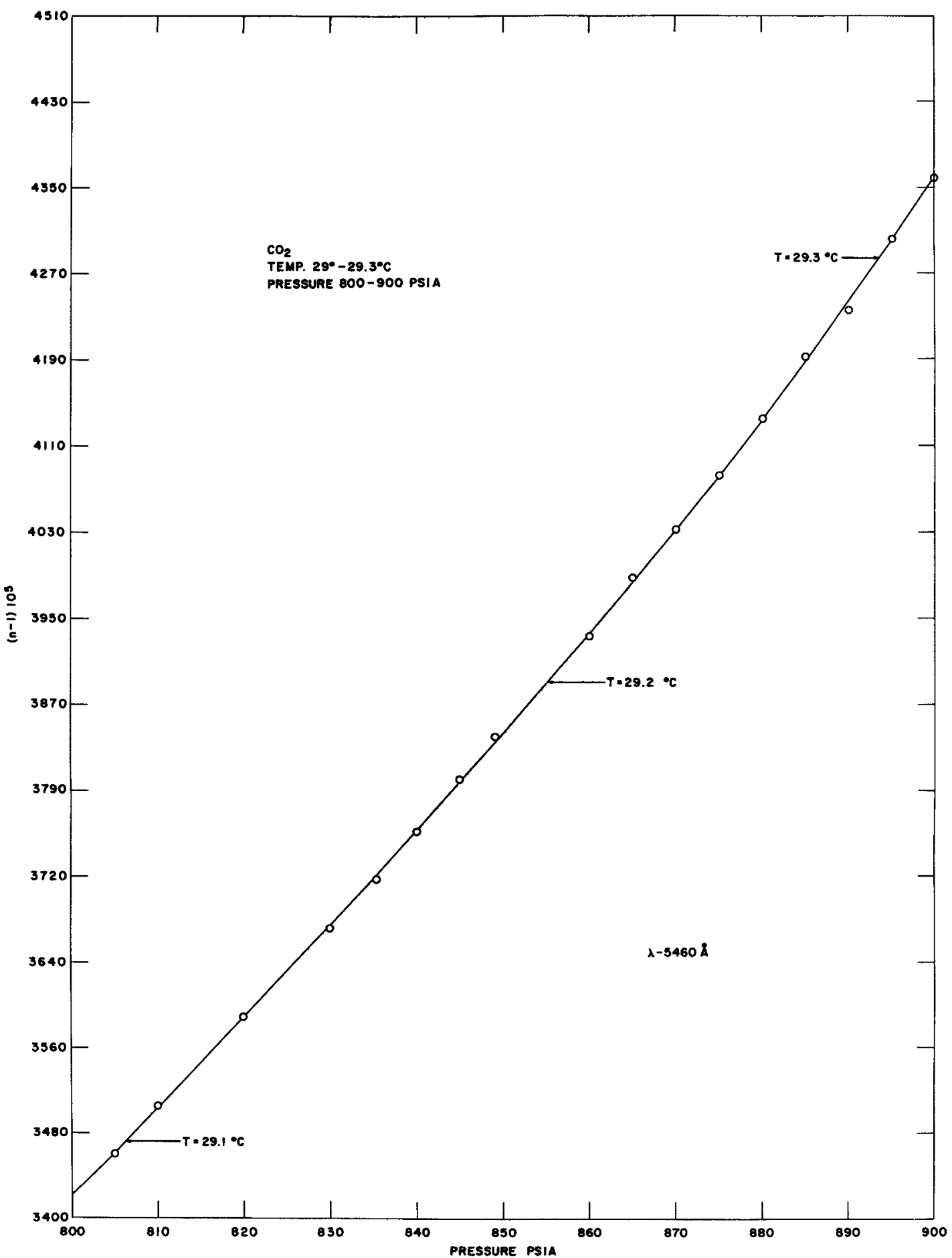




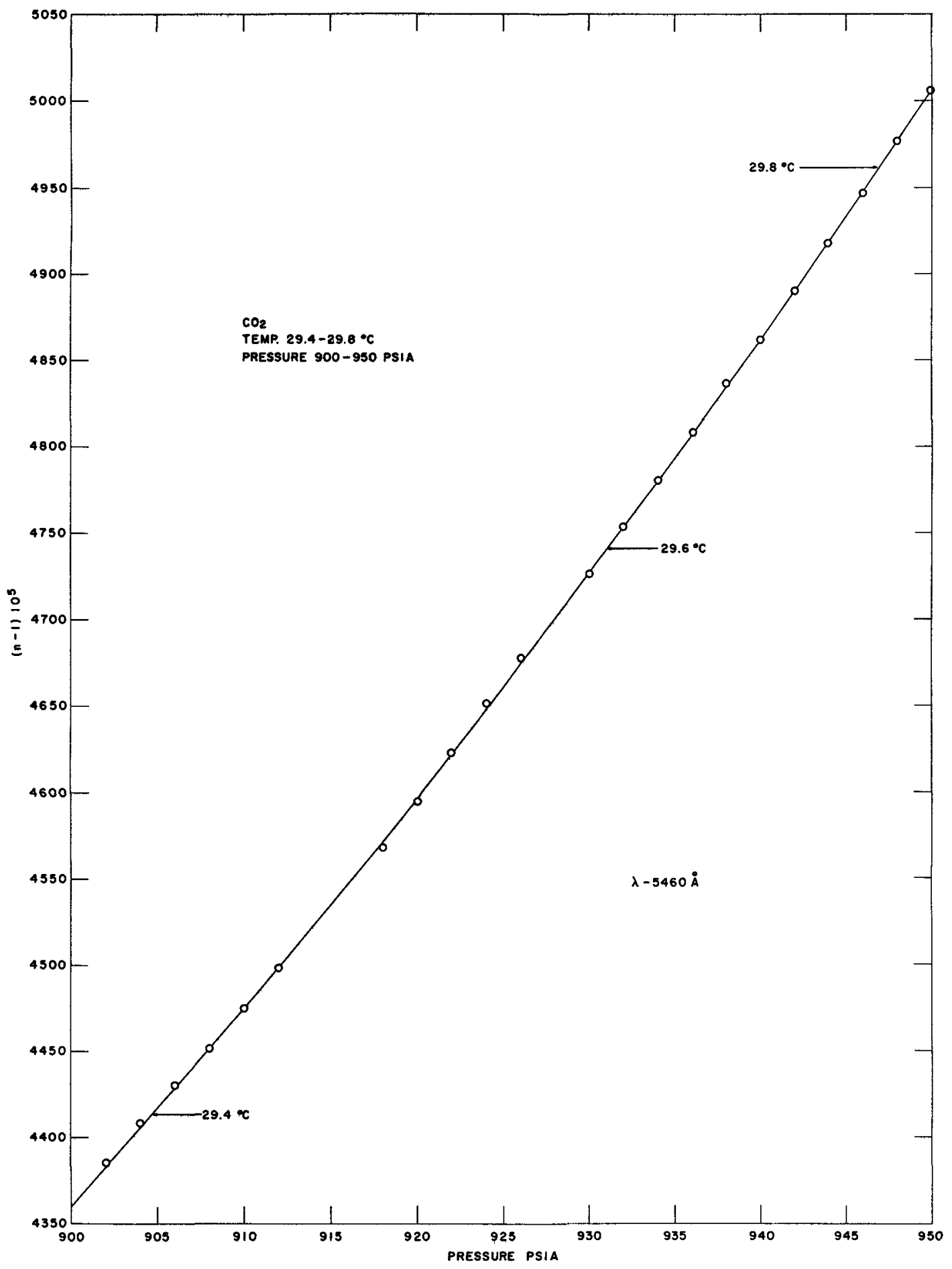




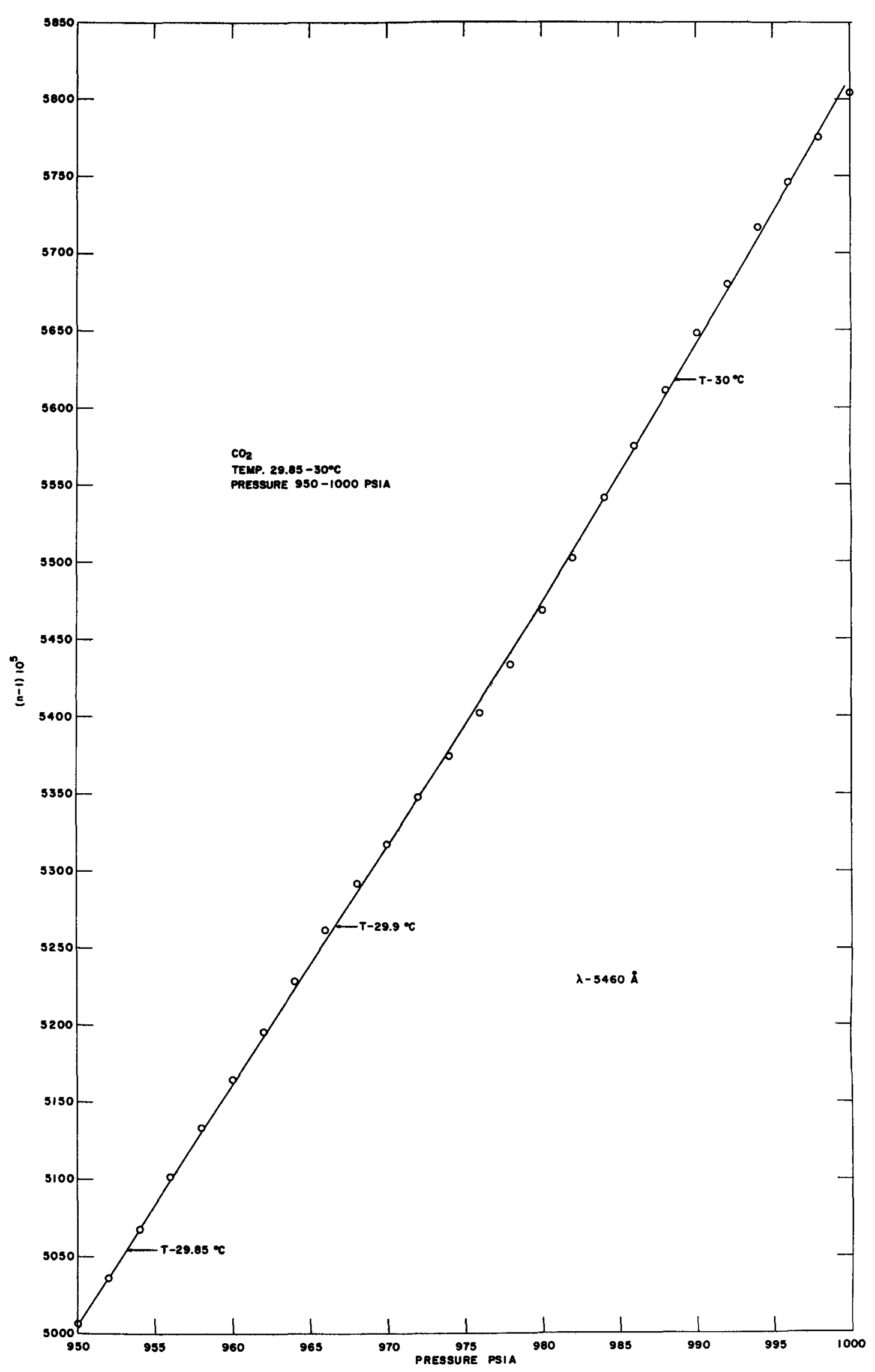




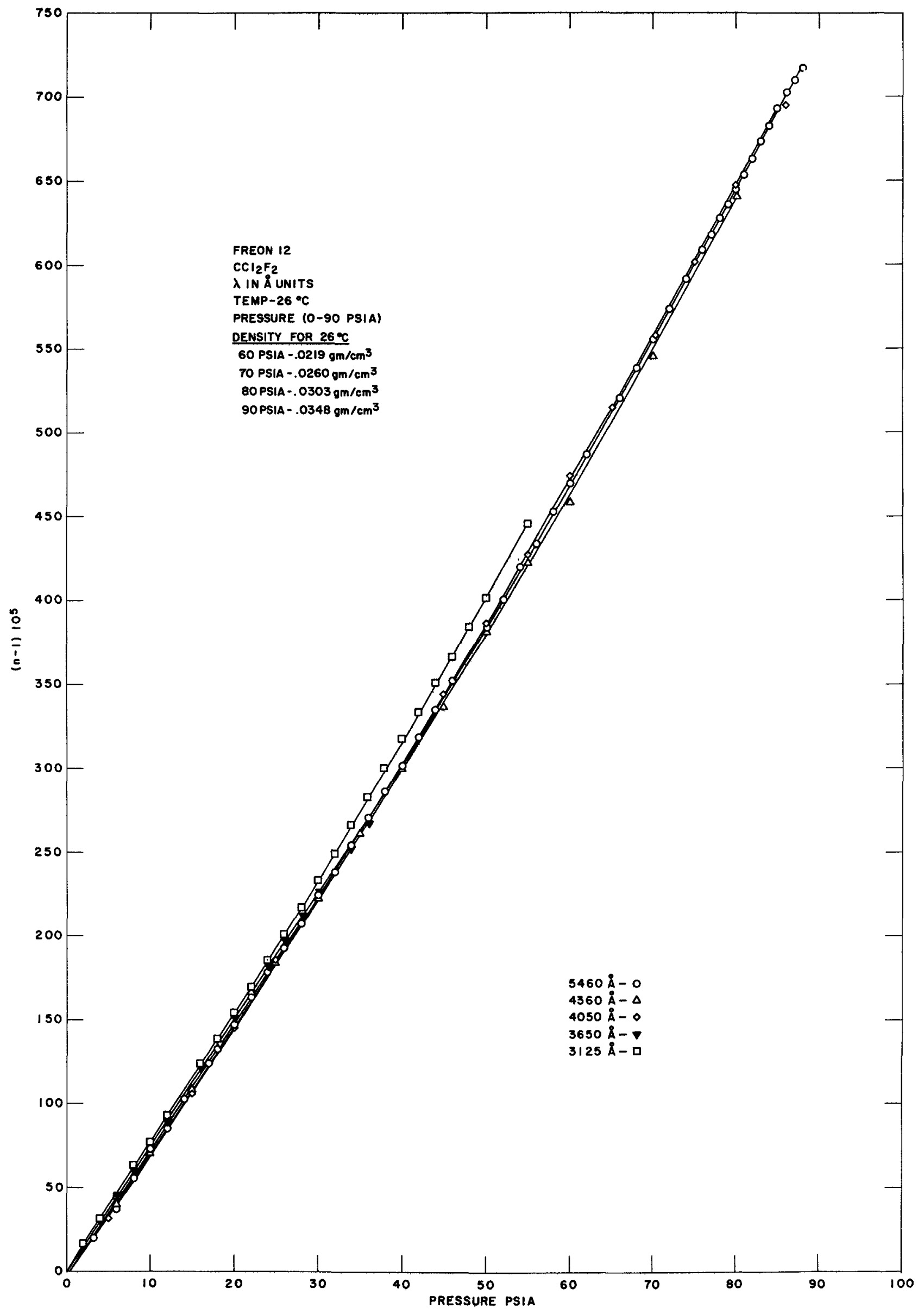




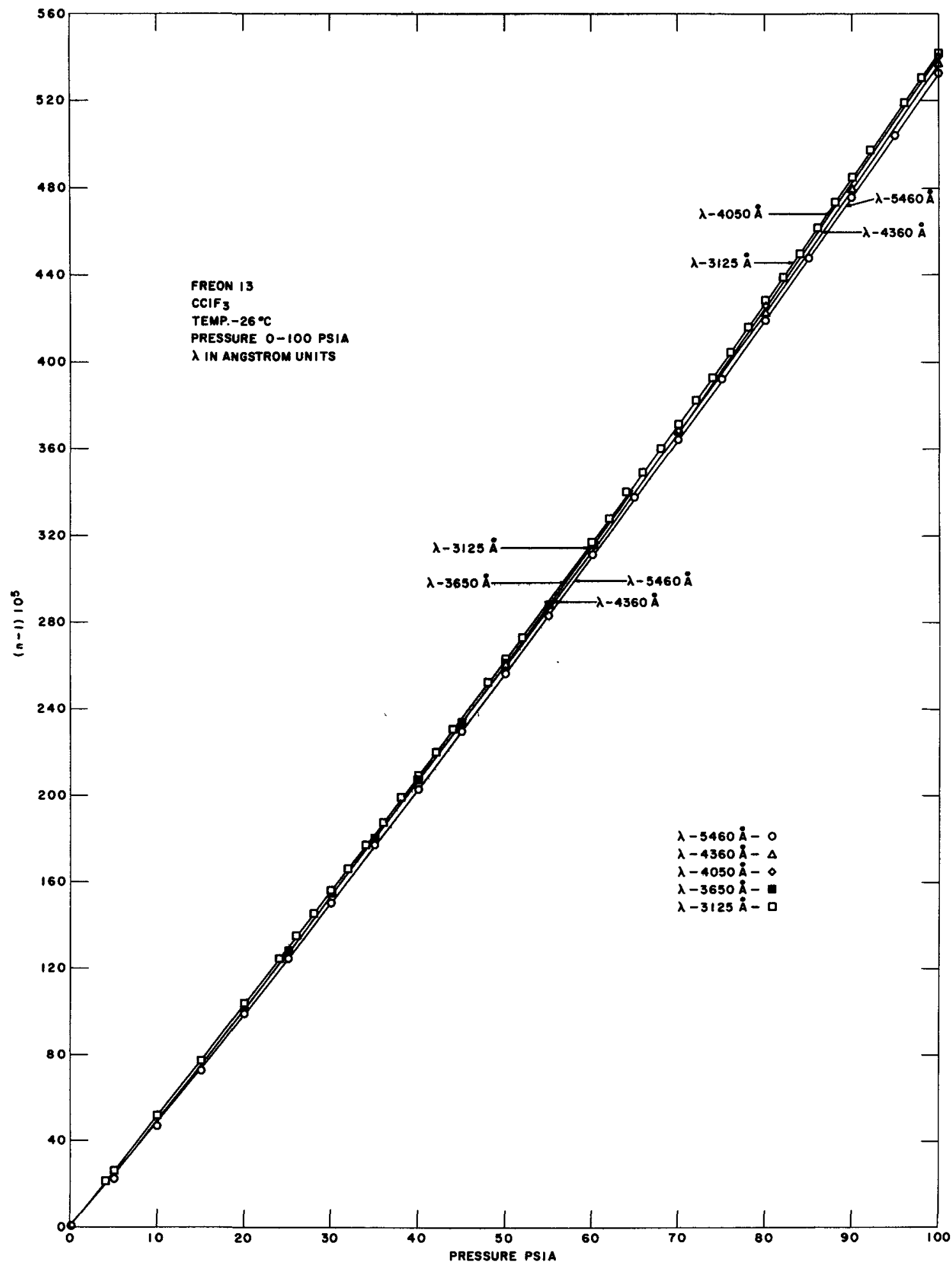




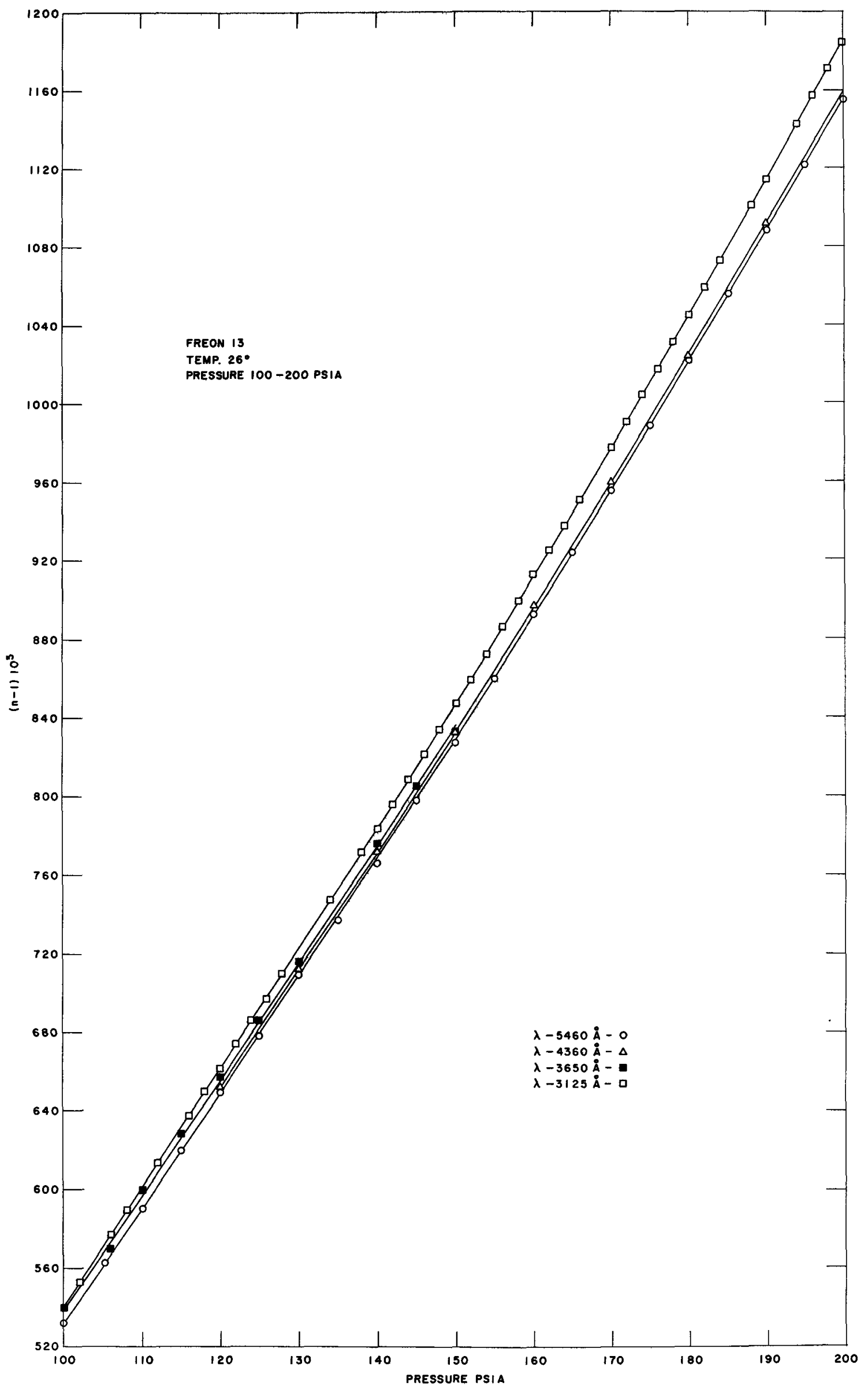




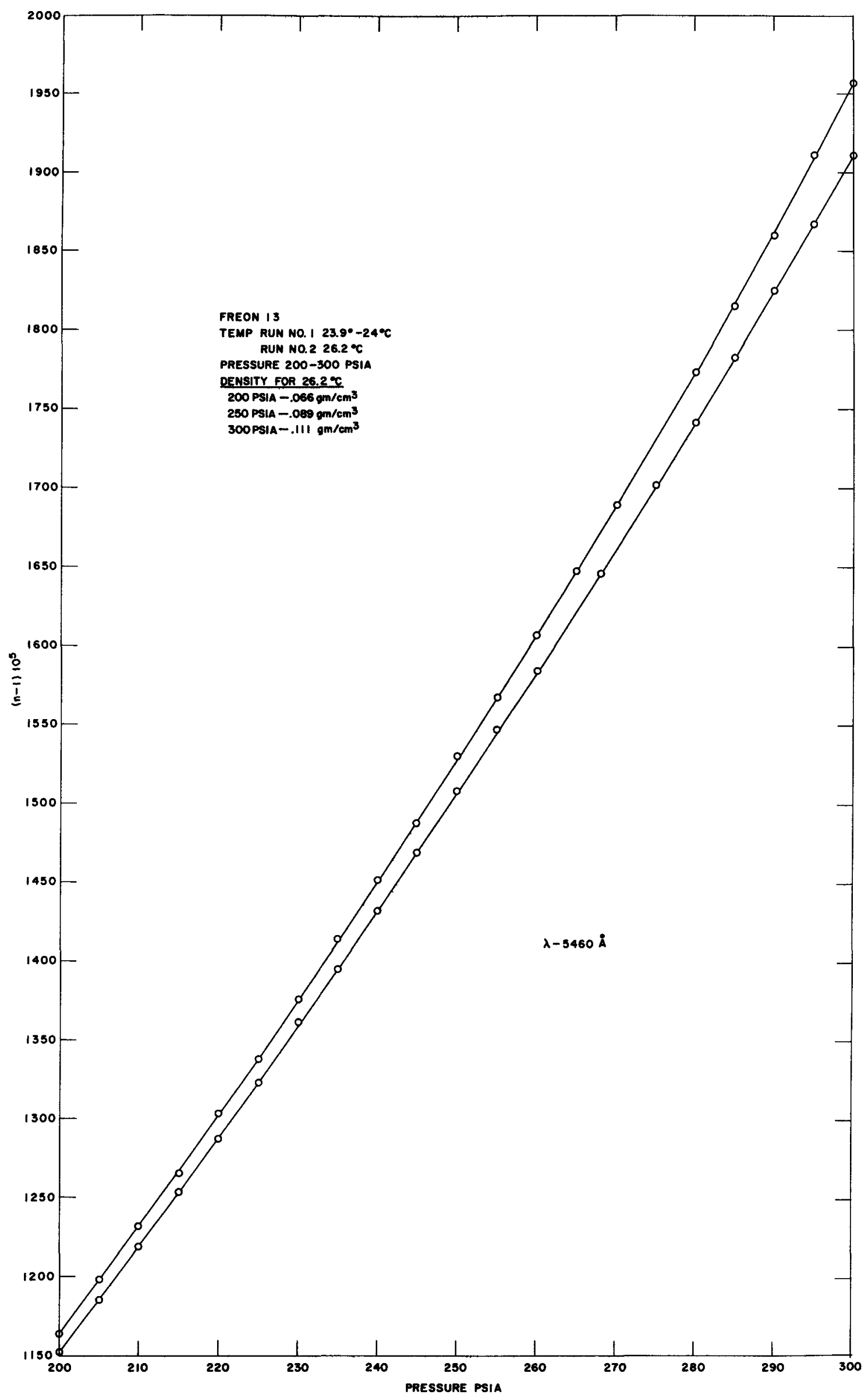




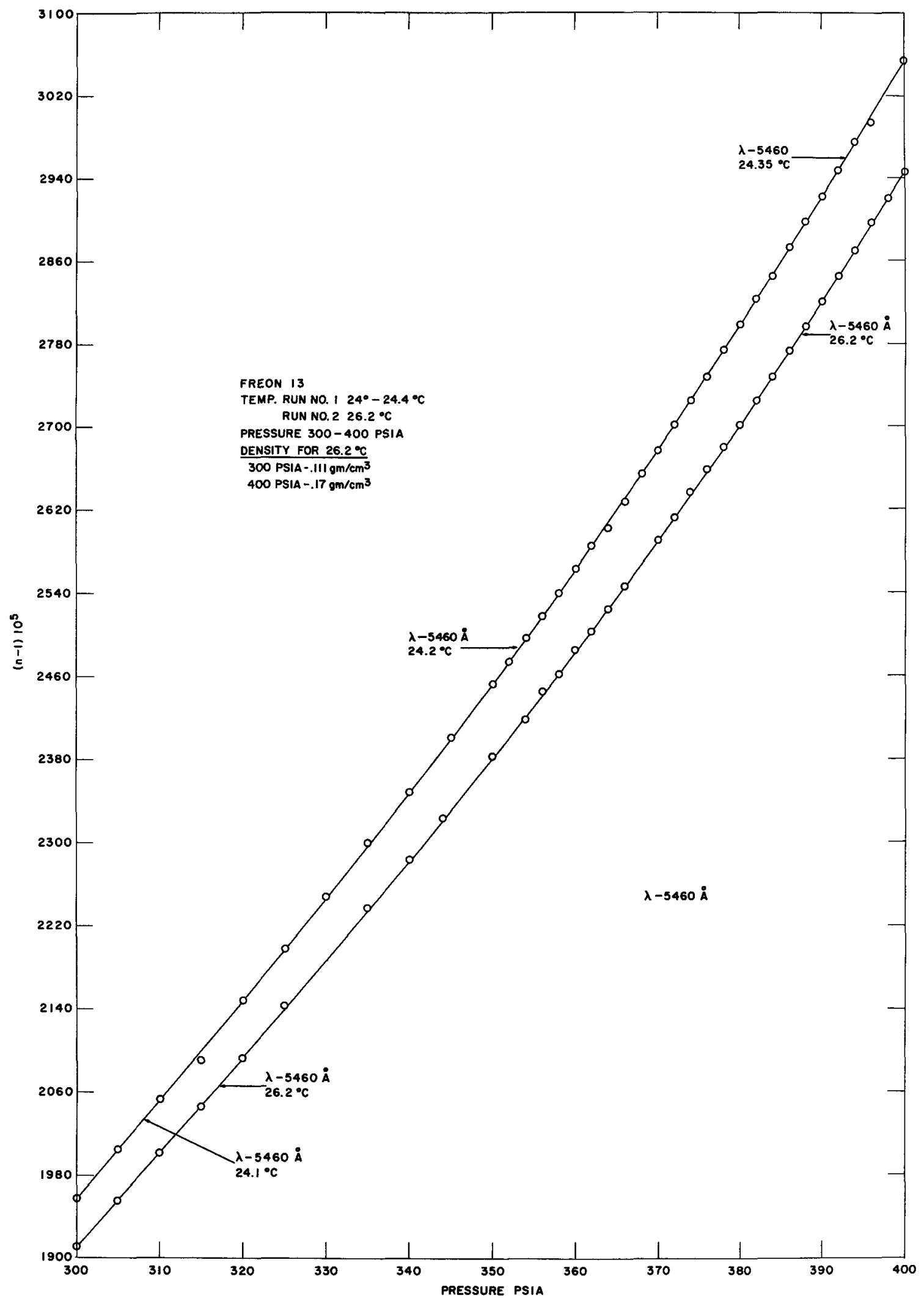




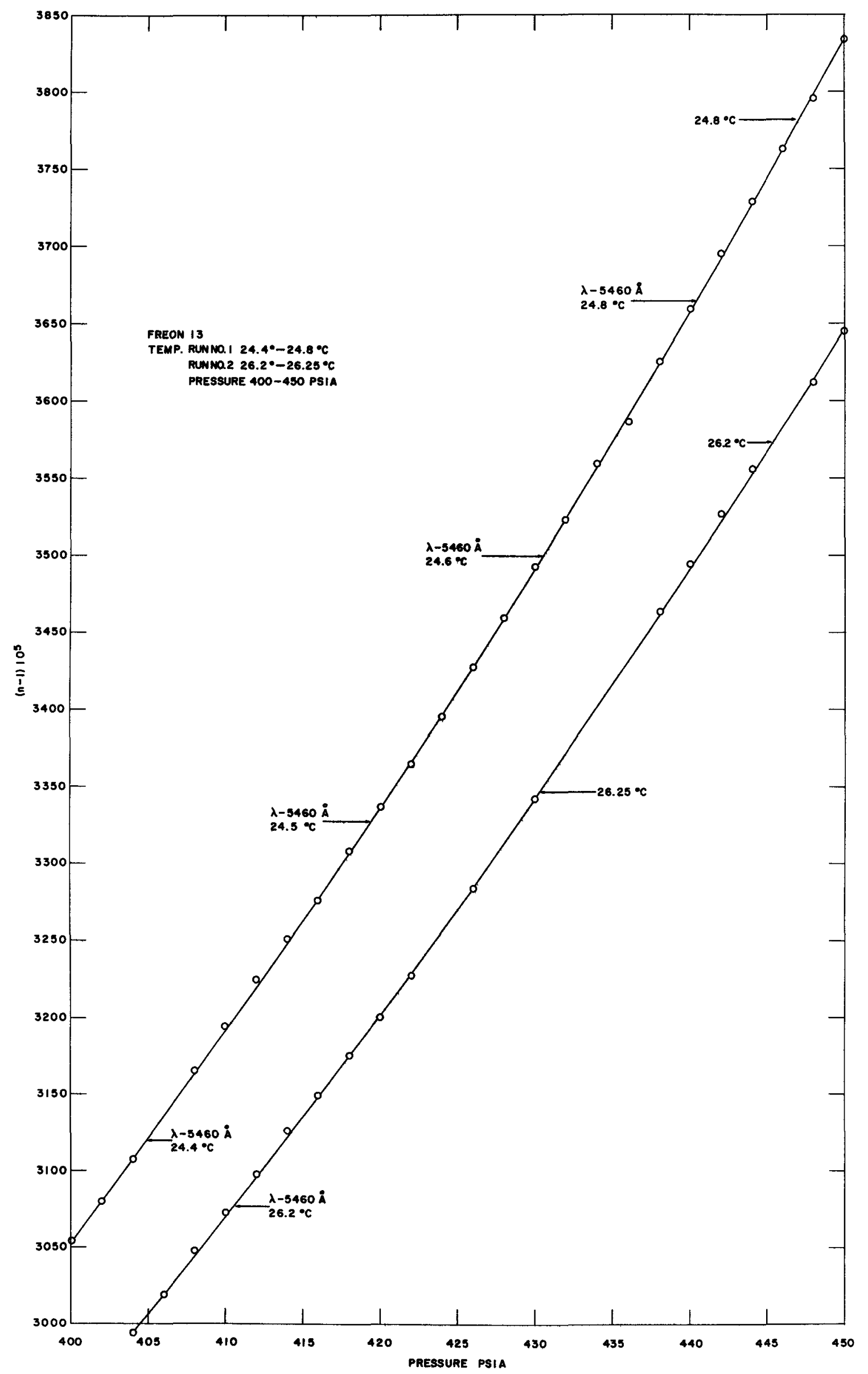




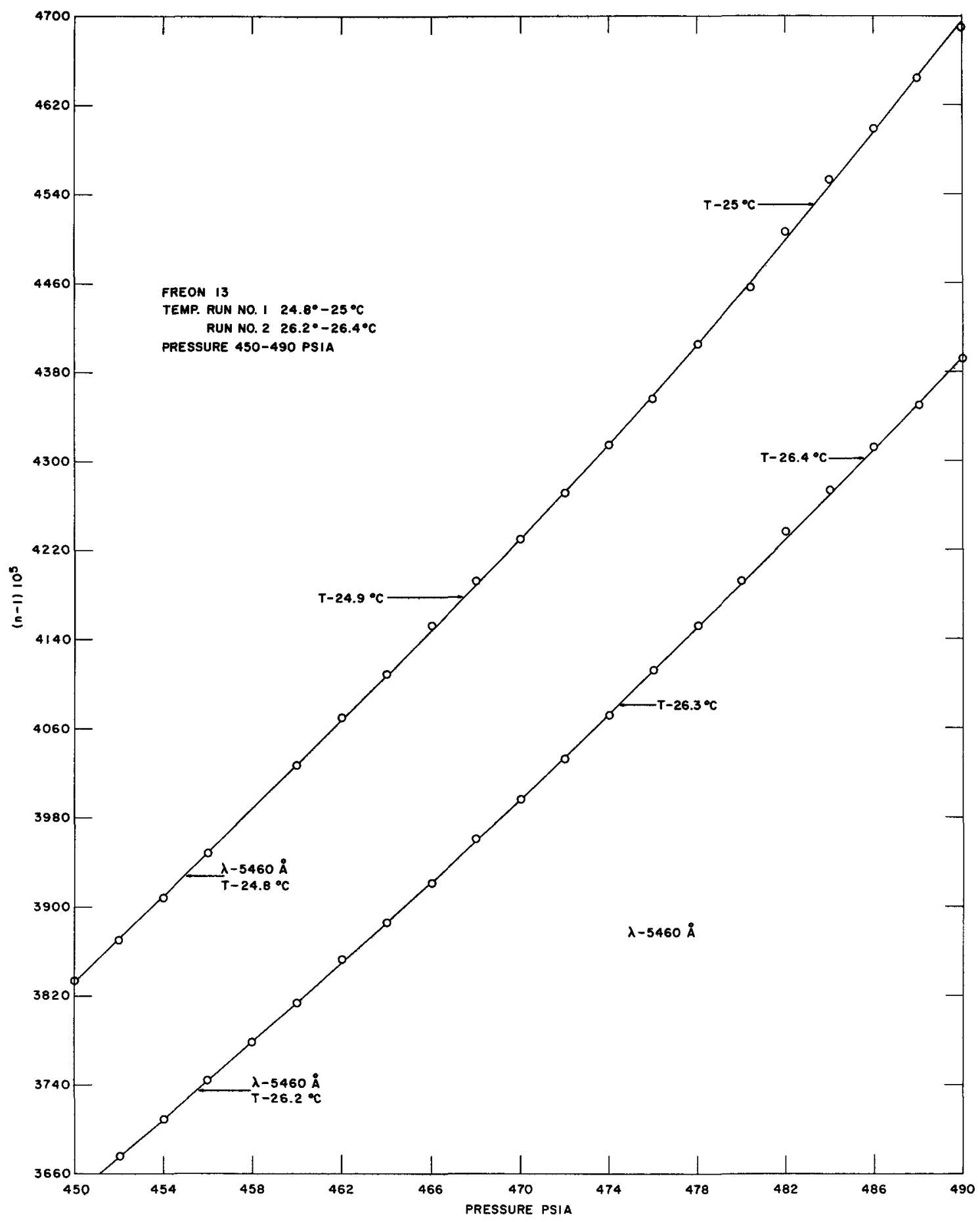




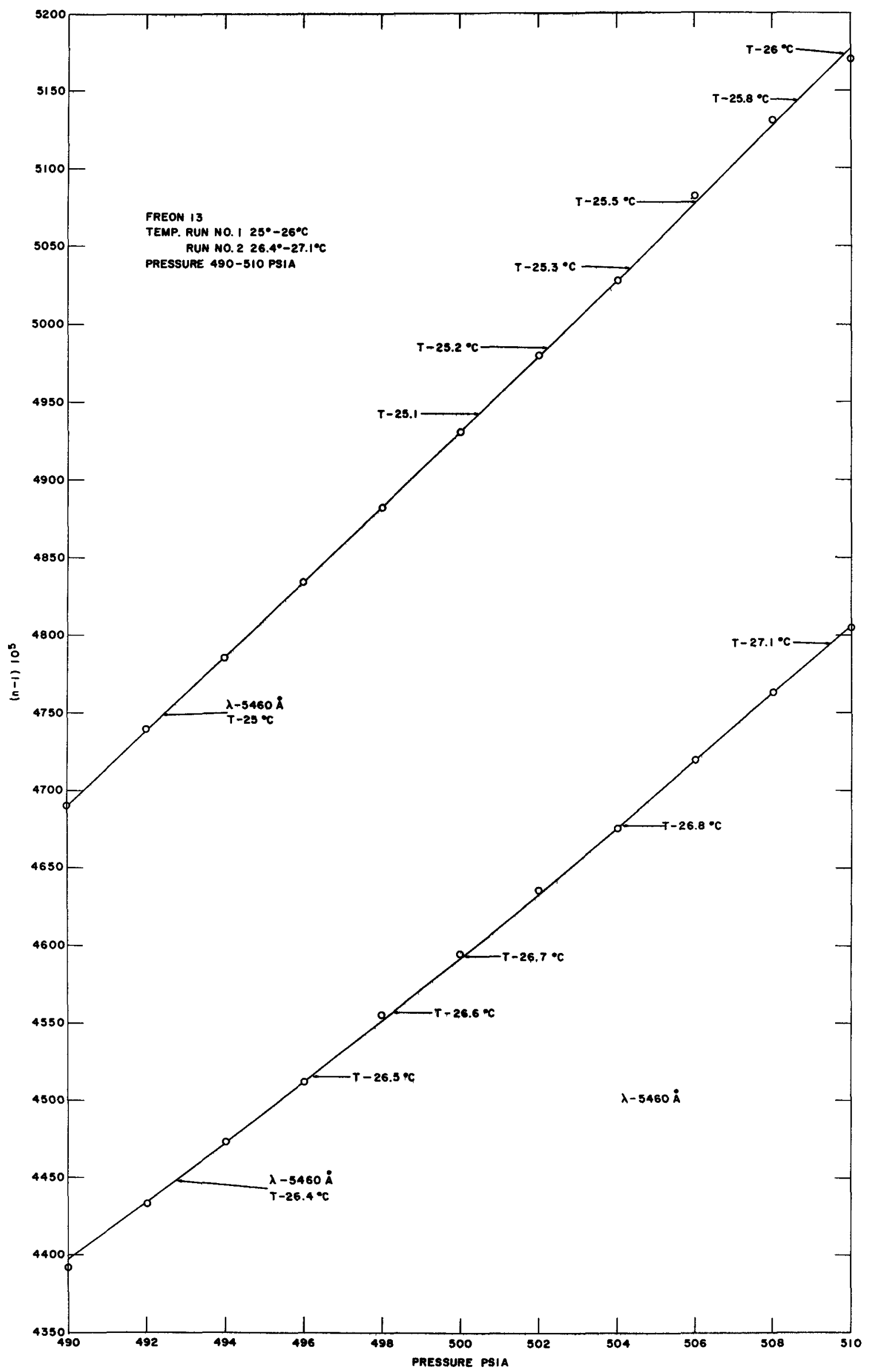




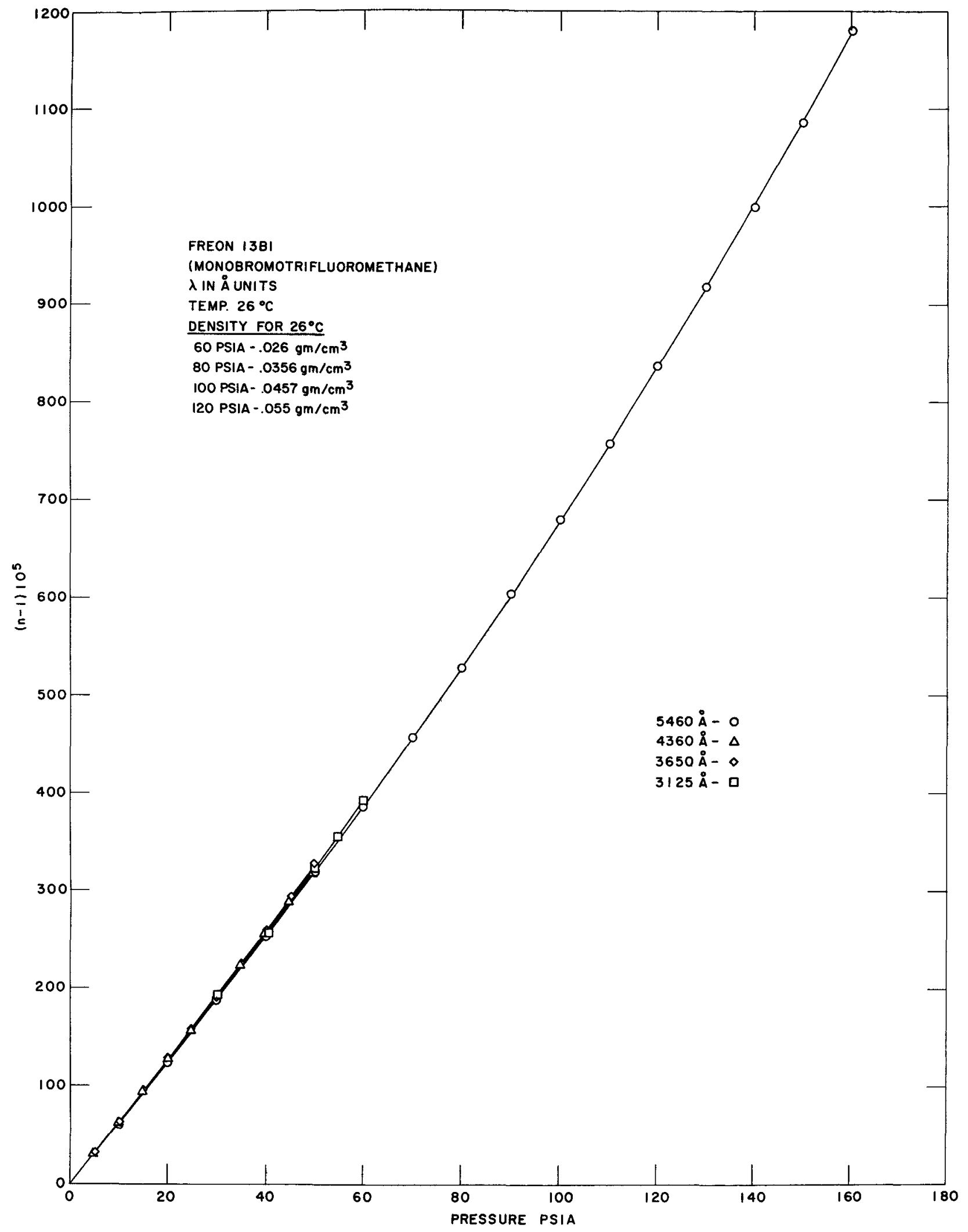




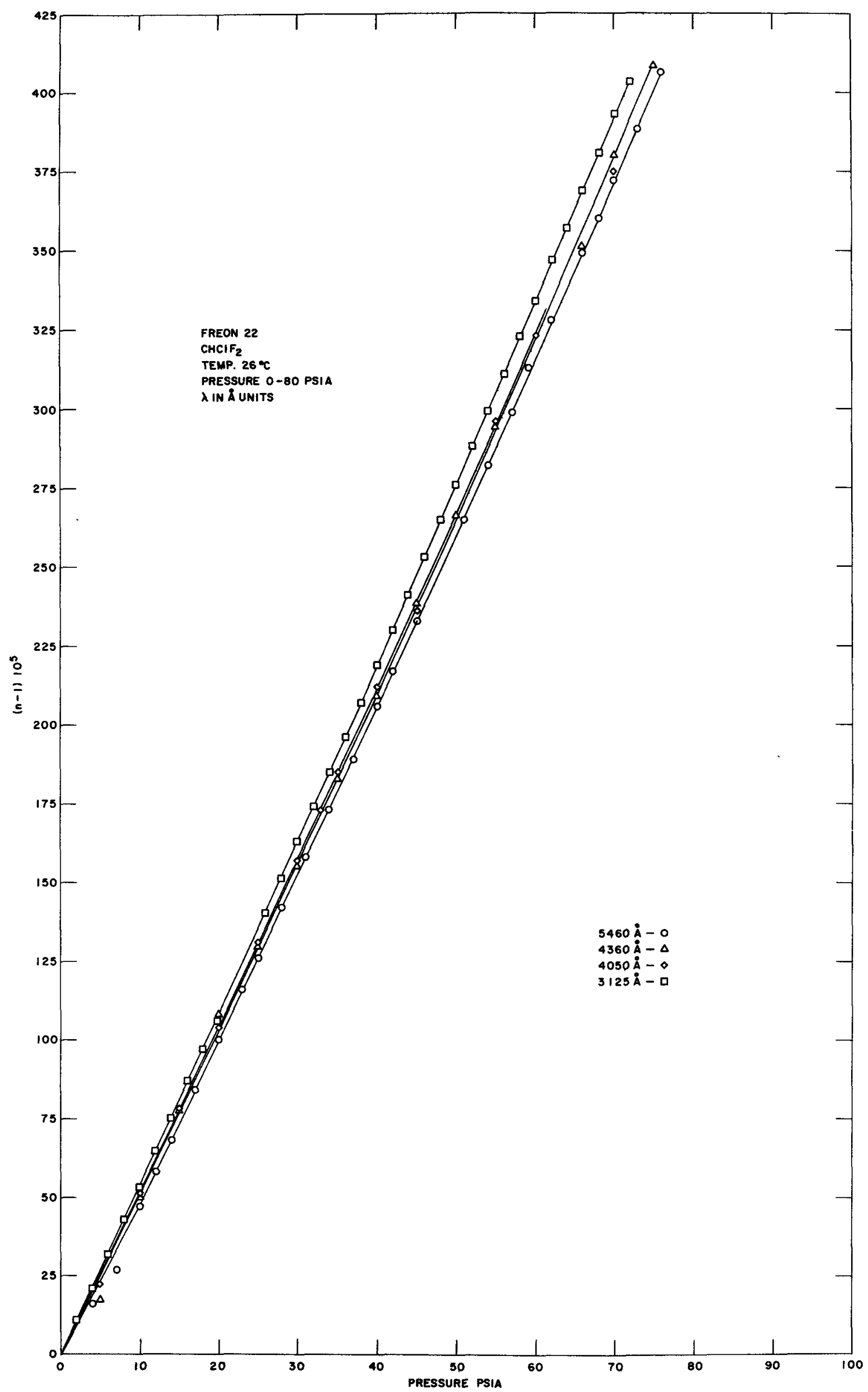




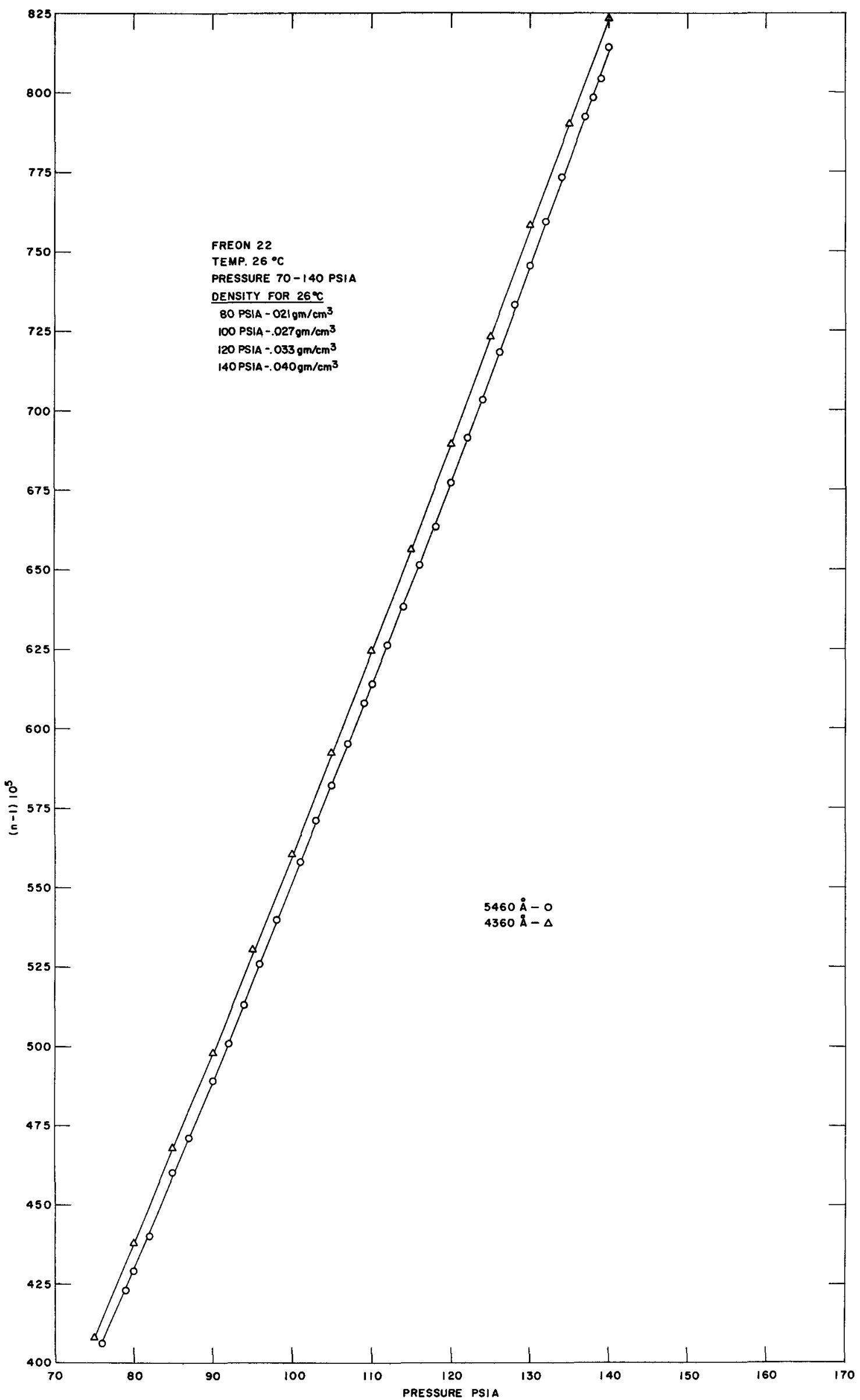




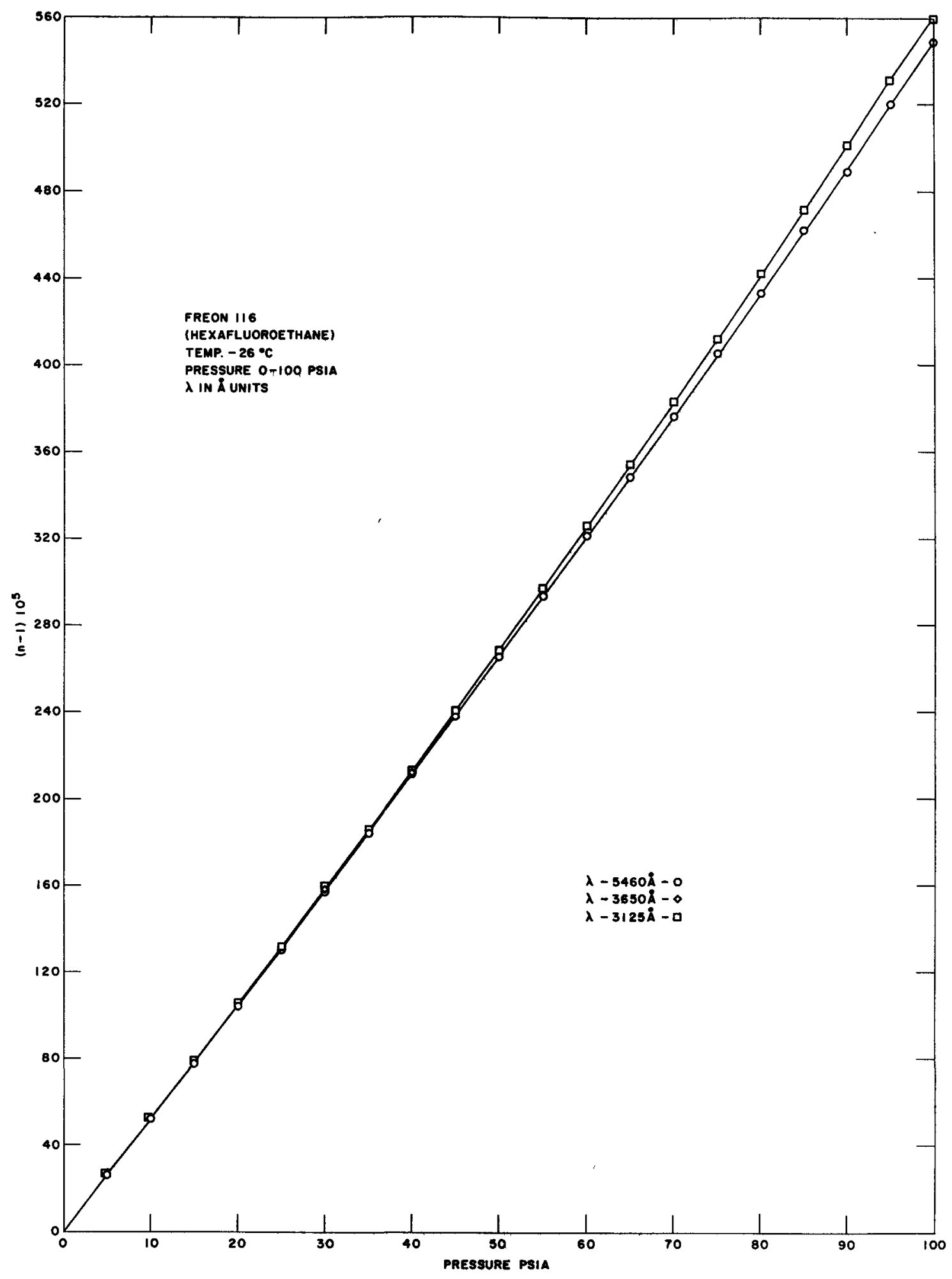



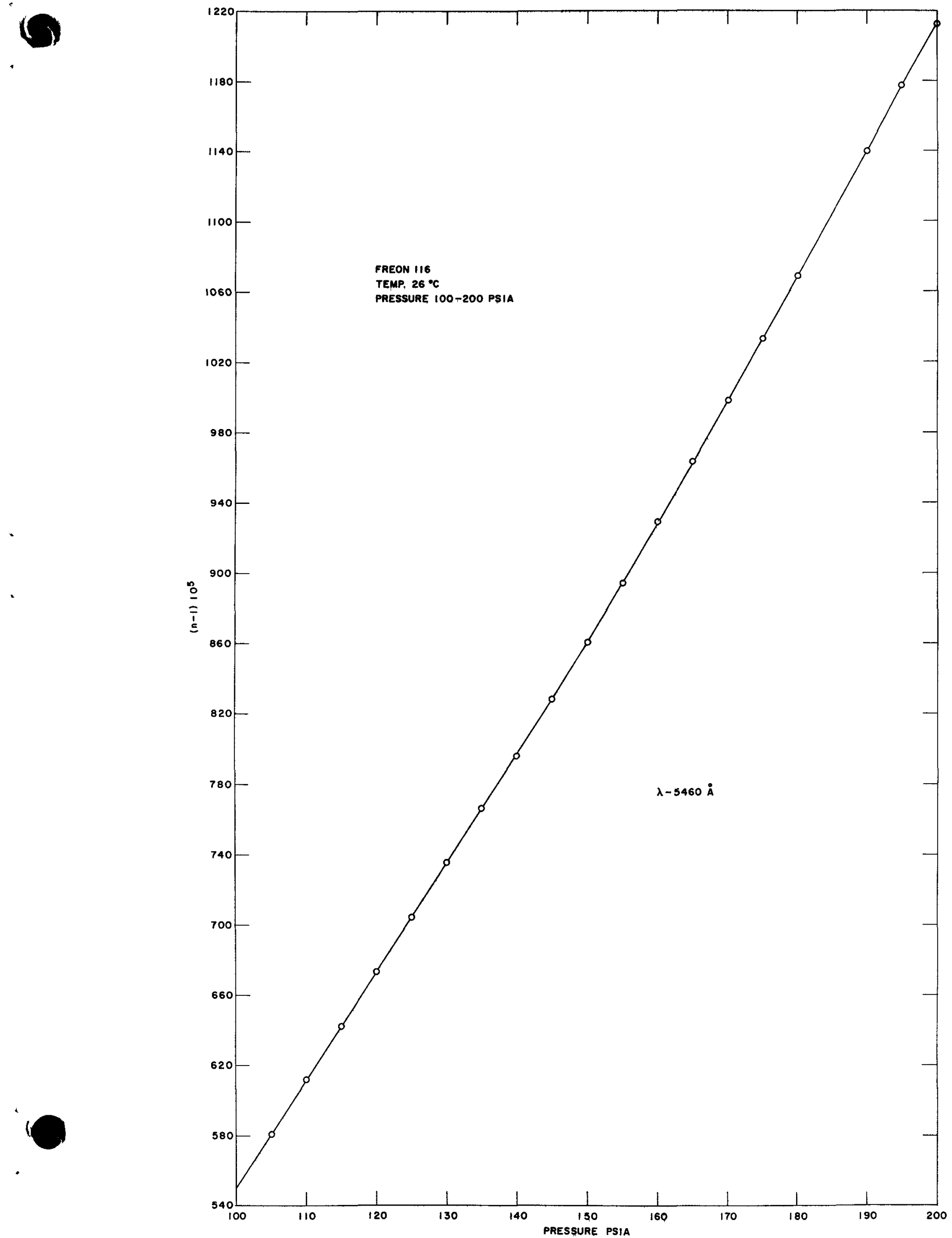


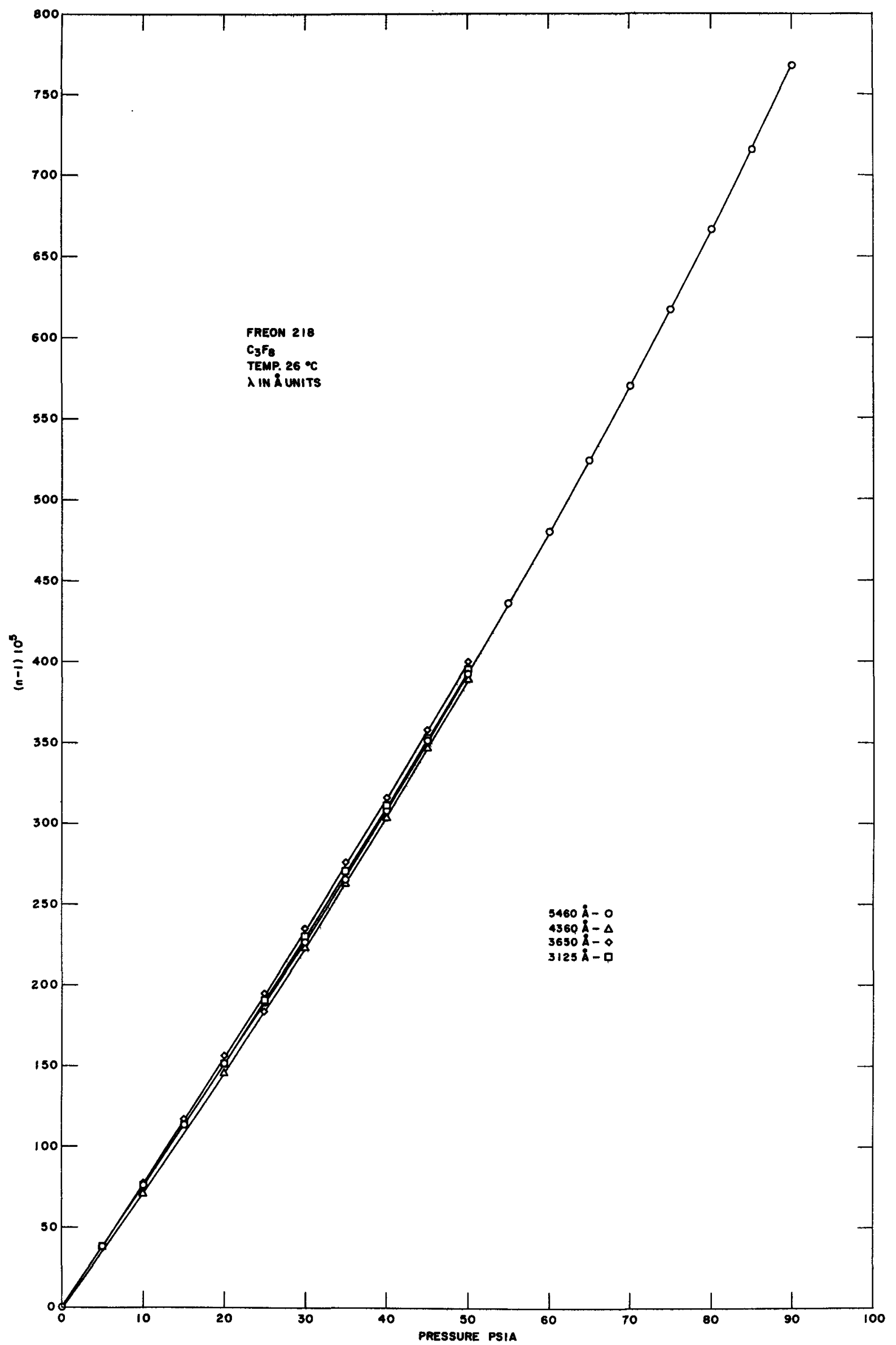




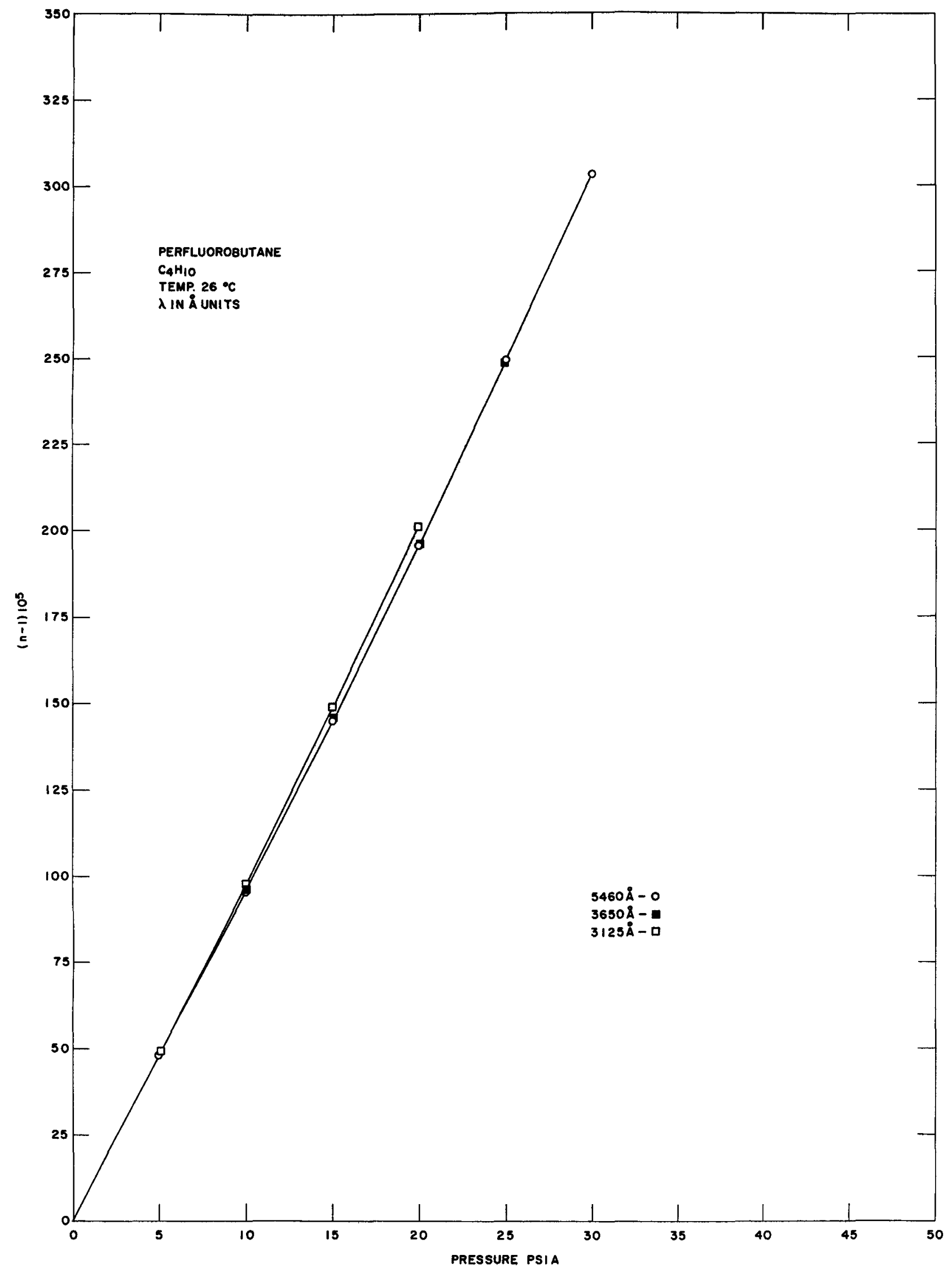

